\title{
Conodont biostratigraphy of the upper Frasnian-lower Famennian transitional deposits in the Shotori Range, Tabas area, Central-East Iran Microplate
}

\author{
Ali Bahrami, CARlo CORRADINI, D. JefFrey OVER \& MeHDI YAZDI
}

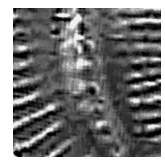

\begin{abstract}
A rich and diverse conodont fauna from upper Frasnian and lower-middle Famennian strata in three sections Ghale-kalaghu, Howz-e-dorah 1 and Howz-e-dorah 2 - in the southern Shotori Range of central Iran contains forty-five taxa belonging to eight genera, dominated by icriodids and polygnathids, from the Lower rhenana Zone to the velifer Zone (= Uppermost marginifera Zone). A hiatus is documented across the Frasnian/Famennian boundary that possibly includes the Upper rhenana to the Middle triangularis Zone. $•$ Key words: conodonts, Shotori Range, Iran, Devonian, Frasnian, Famennian.
\end{abstract}

BAHRAmi, A., CORRADINI, C., Over, D.J. \& YAZDI, M. 2013. Conodont biostratigraphy of the upper Frasnian-lower Famennian transitional deposits in the Shotori Range, Tabas area, Central-East Iran Microplate. Bulletin of Geosciences 88(2), 369-388 (9 figures, 3 tables). Czech Geological Survey, Prague. ISSN 1214-1119. Manuscript received March 16, 2012; accepted in revised form December 17, 2012; published online February 8, 2013; issued June 7, 2013.

Ali Bahrami, Department of Geology, University of Isfahan, Isfahan, I.R. Iran; Bahrami_geo@yahoo.com • Carlo Corradini, Dipartimento di Scienze Chimiche e Geologiche, Università di Cagliari, via Trentino 51, 09127 Cagliari, Italy; corradin@unica.it - D. Jeffrey Over, Department of Geological Sciences, SUNY Geneseo, Geneseo, NY 14454-1401,USA; over@geneseo.edu・Mehdi Yazdi, Department of Geology, University of Isfahan, Isfahan, I.R. Iran; Yazdimehdi@yahoo.com

The Shotori Range is part of a north-south oriented mountain system, which separates the Lut Desert of eastern Iran from the central Iranian desert depression in the northern part of the "Central-East Iran Microplate". The investigated area belongs to the "Jamal Mountains" and is located near the village of Sorond and the Chiruk Silicic Sand mine, approximately $75 \mathrm{~km}$ southeast of Tabas (Fig. 1).

Iran is a structural collage of several microplates that was situated at the northern margin of Gondwana during the Palaeozoic along with a small area in the north-east, the Kope-Dagh, which was part of Laurussia (Berberian \& King 1981, Scotese 2001). The Gondwanan part was located about $20^{\circ}-25^{\circ}$ south of the equator (Golonka et al. 1994) and was covered by a large shelf sea during the Palaeozoic (Wendt et al. 2002).

In the Shotori Range a sedimentary sequence about 5000 meters thick, ranging from the Lower Devonian to the Paleogene, is exposed. Devonian strata are represented by thick sequences of shallow water sediments. Several sections were measured by various authors to describe the stratigraphy of the region, but never in detail. A disconformity at the Frasnian/Famennian boundary has been noted (i.e. Yazdi 1999, Ashouri 2004, Wendt et al. 2005, Gholamalian et al. 2009, Gholamalian 2007,
Bahrami et al. 2011b), but the duration of the hiatus was equivocal due to the lack of precise biostratigraphic data.

This report provides detailed conodont stratigraphy across the Frasnian/Famennian Boundary based on close sampling of three sections in the southern part of the Shotori Range, and is part of a detailed study of the stratigraphy of the Upper Devonian and Lower Carboniferous in the Tabas area. The study is connected to a wider project on the Upper Devonian and Lower Carboniferous of Iran, studying in detail some selected sections in various parts of the country, in order to achieve an understanding of the evolution of the depositional environments of this part of North Gondwana. In this respect, papers on the Devonian/Carboniferous boundary in the Tabas area (Bahrami et al. 2011a) and on the Upper Devonian of Kerman province (Bahrami et al. 2011b) were recently published.

\section{Geological settings}

The base of the Devonian sequence in the Shotori Range is marked by several tens of meters of red sandstone of the Padeha Formation. Fossils are rare in this unit and the Early-Middle Devonian age is inferred on the basis of 


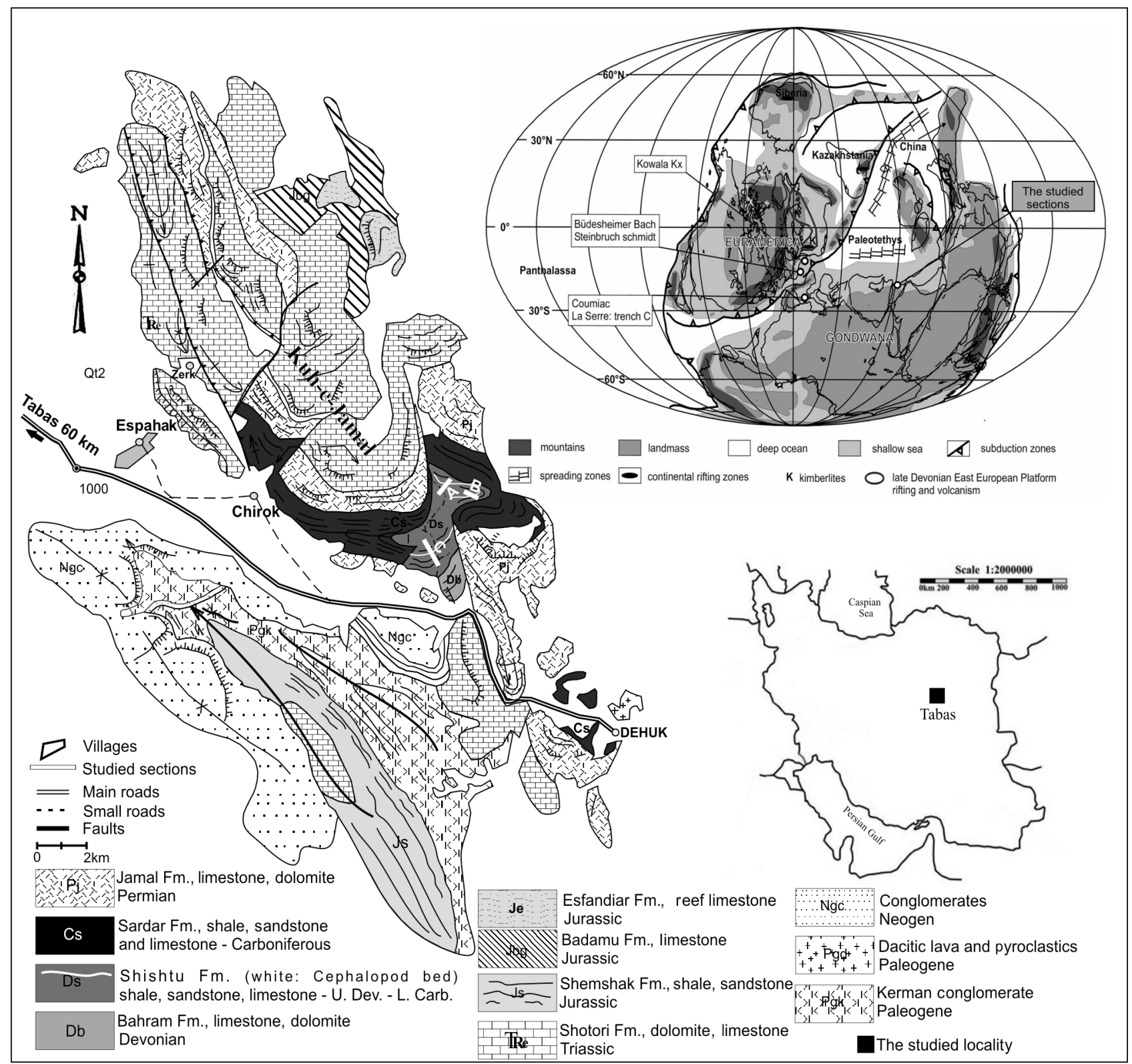

Figure 1. Geological map of the area around the Espahak village, Tabas Province, east central Iran, with indication of the studied sections (redrawn and simplified after Stocklin \& Nabavi 1971). Paleogeographic reconstruction map (modified after Scotese \& McKerrow 1990) showing the location of the investigated area, location of ocean spreading zones and continental rifting zones Racki (1998) in the Late Devonian, as well as some key European Frasnian/Famennian boundary sections modified after Pujol (2005).

adjacent units (Wendt et al. 2002). The sequence continues with the Sizbar Formation, composed primarily of dolostones with rare calcareous intercalations. Wendt et al. (2002) suggested a shallow subtidal to supratidal depositional environment, and defined a Givetian age on the basis of conodonts from Kalshaneh, in the southern part of the Central-East Iran Microplate.

The sequence continues upward with the Bahram Formation, up to $500 \mathrm{~m}$ thick, which consists of thick bedded dark grey limestone in the lower part and massive brown dolomite with minor green shale intercalations in the upper part. The limestones are very fossiliferous, and contain conodonts, brachiopods, tentaculitids, crinoids, bryozoans, rugose and tabulate corals, stromatoporoids, trilobites, and rare mollusks (Wendt et al. 2002). The age of the Bahram Formation in the Shotori Range is limited to the early Frasnian, whereas in other parts of Iran it includes Famennian strata (Wendt et al. 2005, Bahrami et al. 2011b).

The Bahram Formation is conformably overlain by the Shishtu Formation, a carbonate and clastic unit (Stocklin \& Nabavi 1971) that is informally subdivided into two subformations: "Shishtu-1" and "Shishtu-2". 
Ghale-kalaghu section

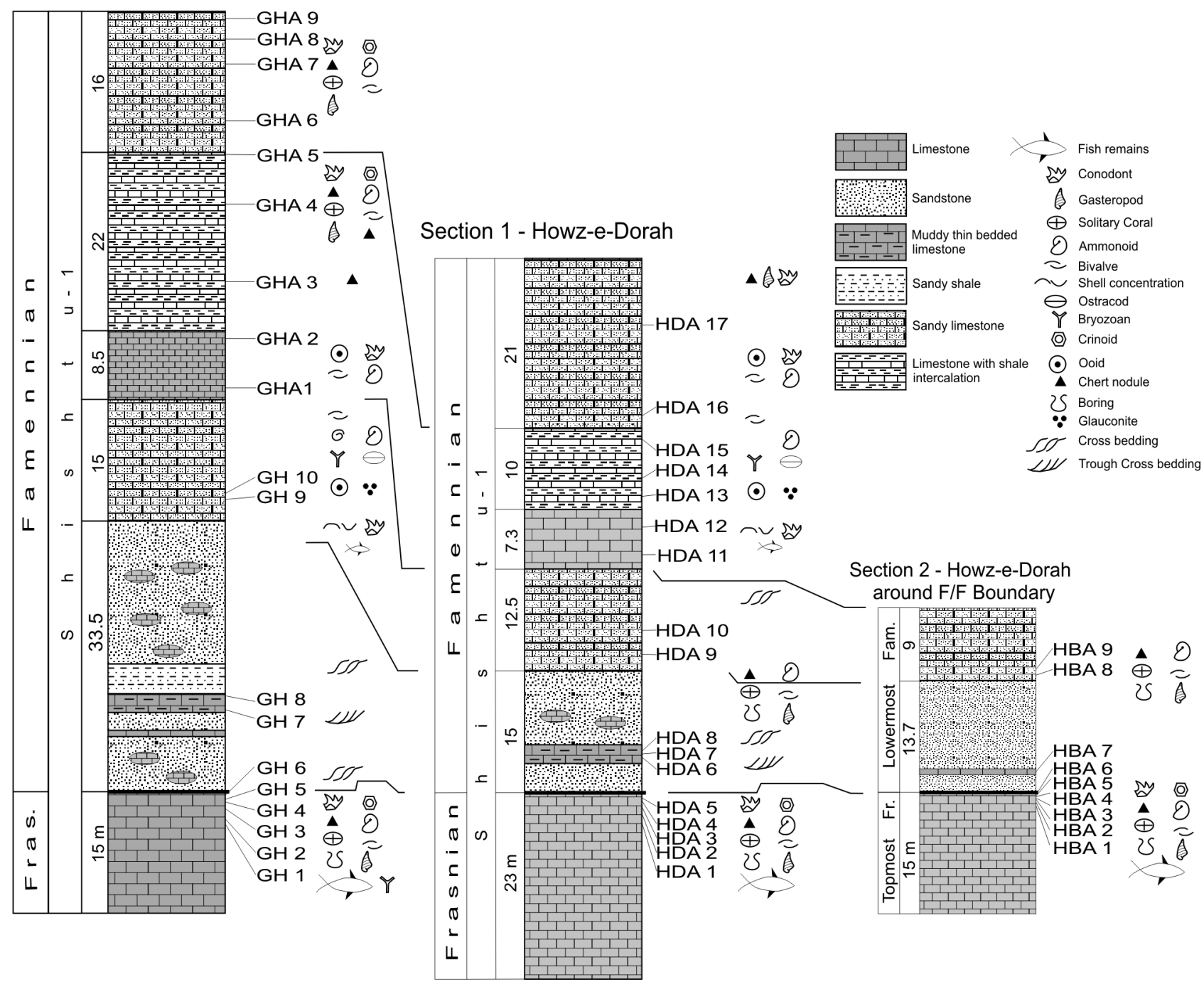

Figure 2. Stratigraphic log, samples position, fossil content and sedimentary features of the Ghale-kalaghu, Howz-e-dorah 1 and 2 sections.

The Shishtu 1 subformation is more than $300 \mathrm{~m}$ thick, consisting of dark green shale interbedded with quartzitic sandstones and intercalations of fossiliferous limestone; the topmost $28 \mathrm{~m}$ (beds 23-26 of Stocklin et al. 1965) are represented by highly fossiliferous shale, sandstone, oolitic limestone, and iron oolites, which have been named the "Cephalopod Bed" (Stocklin et al. 1965). It ranges from the middle Frasnian to the late Famennian. The base of the "Cephalopod Bed" is diachronous, and ranges from late Frasnian in Kale-sardar to Famennian in Howz-e-dorah (Wendt et al. 1997, 2005; Yazdi 1999). The Shishtu 2 subformation is about $250 \mathrm{~m}$ thick and consists of interbedded limestone and shale. The base is marked by the "Mush Horizon", a dark grey shale with an intercalation of strongly gypsiferous pink shale, and a thin brachiopod-rich limestone layer which indicates the start of the Tournaisian.
The Shishtu Formation as a whole ranges from middle Frasnian to Viséan. The Frasnian/Famennian boundary falls within the top unit of Shishtu 1 subformation at the base of the White Sandstone Beds (WSB) marker between "Placoderm beds" and "Cephalopod-bearing beds" (Fig. 3A-E). The Devonian/Carboniferous boundary can be traced between the "Cephalopod Bed" and the "Mush Horizon" at the boundary between the Shishtu-1 and Shishtu-2 subformations (Bahrami et al. 2011a).

\section{The Frasnian/Famennian boundary in Iran}

Beside the Shotori Range, upper Frasnian and lower Famennian rocks are relatively widespread in Iran, as they are documented in several parts of the country. However, the boundary is often missing, because of hiatuses and/or 
unconformities between the two stages, or difficult to locate precisely, due to lacking of biostratigraphically relevant fauna.

In the central Alborz Mountains, north Iran, Upper Devonian rocks belongs to the Geirud Formation (Assereto 1963), a huge sequence of shales, quartzites, sandstones, conglomerates and sandy limestones deposed in a fluvial deltaic to shallow marine environment (Ueno et al. 1997, Wendt et al. 2005, Habibi et al. 2008 and reference therein). The fossils content is in general scarce and is mainly represented by brachiopods and palynomorphs, that allow to date the unit to a late Middle Devonian to Early Carboniferous, but are not sufficient to precisely locate the $\mathrm{F} / \mathrm{F}$ boundary in any section.

In the eastern Alborz Mountains this time frame is occupied by the Khoshyeilagh Formation (Bozorgnia 1973), a thick sequence of limestones, dolostones, sandstones, siltstones and shales. Fossils are always abundant: brachiopods, tentaculitids, crinoids, rugose and tabulate corals, gastropods and trilobites. Wendt et al. (2005) subdivided the unit into three lithologically characterized members: a lower carbonate, a siliciclastic and an upper carbonate member. These authors locate the Frasnian/Famennian boundary in the lower part of the upper carbonate member in the Khoshyeilagh and Mighan sections on the basis of brachiopod and tentaculite fauna.

In the Kerman Province (southern part of the Central-East Iran microplate) Upper Devonian rocks belong to the Bahram Formation that in some places spans the whole Famennian. However, due to tectonics and the level of erosion connected with the pre-Permian emersion often it is not exposed completely (Wendt et al. 2002). The unit, deposited in a shallow water sedimentary environment, is always very fossiliferous, but biostratigraphically relevant fossil groups are not abundant. Thus the precise position of the F/F boundary can be often only inferred or approximated (i.e. Shams Abad section, Bahrami et al. 2011b).

In central-west Iran (provinces of Isfahan and Yazd) Upper Devonian rocks are referred to the Bahram Fm. (Wendt et al. 2005) or to an "equivalent of the Shishtu Fm." (Hairapetian \& Yazdi 2003). In these areas a precise position of the F/F boundary has never been established, too.

\section{The studied sections}

Three sections were measured in the southern part of the Shotori Range, approximately $75 \mathrm{~km}$ southeast of Tabas, close to the village of Sorond and the Chiruk Silicic Sand mine (Fig. 1). The area is accessible by an unpaved track off the Tabas-Dihuk road.

\section{Ghale-kalaghu section}

The Ghale-kalaghu section (Figs 1, 2, 3a, 4) is located about $1 \mathrm{~km}$ south of the Chiruk mine, at coordinates: base $33^{\circ} 20^{\prime} 40.86^{\prime \prime} \mathrm{N}-57^{\circ} 20^{\prime} 09.72^{\prime \prime} \mathrm{E}$ and top: $33^{\circ} 20^{\prime} 49.19^{\prime \prime}$ $\mathrm{N}-57^{\circ} 20^{\prime} 05.84^{\prime \prime} \mathrm{E}$.

The section exposes about $105 \mathrm{~m}$ of the Upper Devonian Shishtu 1 subformation and includes (from top to base):

- $16 \mathrm{~m}$ of pink to red/brown sandy oolitic limestone with cherts. Fossil content represented by conodonts, bivalves, gastropods, and rare goniatites and crinoid stems;

$-22 \mathrm{~m}$ of brown to pink, thin bedded limestone with shale and marl intercalations. Fossils: gastropods, bivalves, crinoid stems, rare solitary corals, and conodonts;

$-8.5 \mathrm{~m}$ of yellow thin bedded limestone with crushed macrofauna (mainly bivalves and goniatites) and conodonts;

$-15 \mathrm{~m}$ of yellow to pink, and dark brown oolitic sandy limestone with brachiopods, bivalves, ostracodes, conodonts, and rare goniatites;

$-33.5 \mathrm{~m}$ of white to brown sandstone with ferruginous fine grained sandstones at the base with grey to dark sandy shale and sandstones, and a few thin bedded sandy limestones. The base of this unit is a disconformity;

$-25 \mathrm{~m}$ of nodular grey to brown limestone with alternation of grey to brown mudstone. Fossil content includes conodonts, rare goniatites, placoderm remains, crinoid stems, small solitary corals, and bryozoans. This unit is informally named the "placoderm-bearing beds".

\section{Howz-e-dorah 1 section}

The Howz-e-dorah 1 section (Figs 1, 2, 3C, E, 5) is located about 500 m northeast of the Chiruk mine, at coordinates: base $33^{\circ} 22^{\prime} 21.07^{\prime \prime} \mathrm{N}-57^{\circ} 20^{\prime} 22.85^{\prime \prime} \mathrm{E}$ and top: $33^{\circ} 22^{\prime} 26.64^{\prime \prime} \mathrm{N}-57^{\circ} 20^{\prime} 29^{\prime \prime} \mathrm{E}$.

The section comprising $88.8 \mathrm{~m}$ of limestone, sandstone, and shale was studied by Yazdi (1999) and Wendt et al. (1997, 2005), who gave a general age, but did not sampled in detail. The lithostratigraphy and fossil content are similar to the Ghale-kalaghu section.

Figure 3. Selected views of the studied sections. $\bullet$ A - the western face of the Ghale-kalaghu section, with indication of the lithostratigraphic units: Mush horizon, Cephalopod beds, White Sandstone Beds (W.S.B.), position of the Frasnian/Famennian and the Devonian/Carboniferous boundaries. $\bullet$ B - view of the sequence across the Frasnian/Famennian boundary in Howz-e-dorah 2 section. $\bullet$ C, D - close view of the upper contact between the White Sandstone Beds and the Cephalopod beds at the Howz-e-dorah 1 (c) and Howz-e-dorah 2 (d) sections. $\bullet$ E - general view of Howz-e-dorah 1 section. 
Ali Bahrami et al. • Late Devonian conodonts from Central-East Iran Microplate
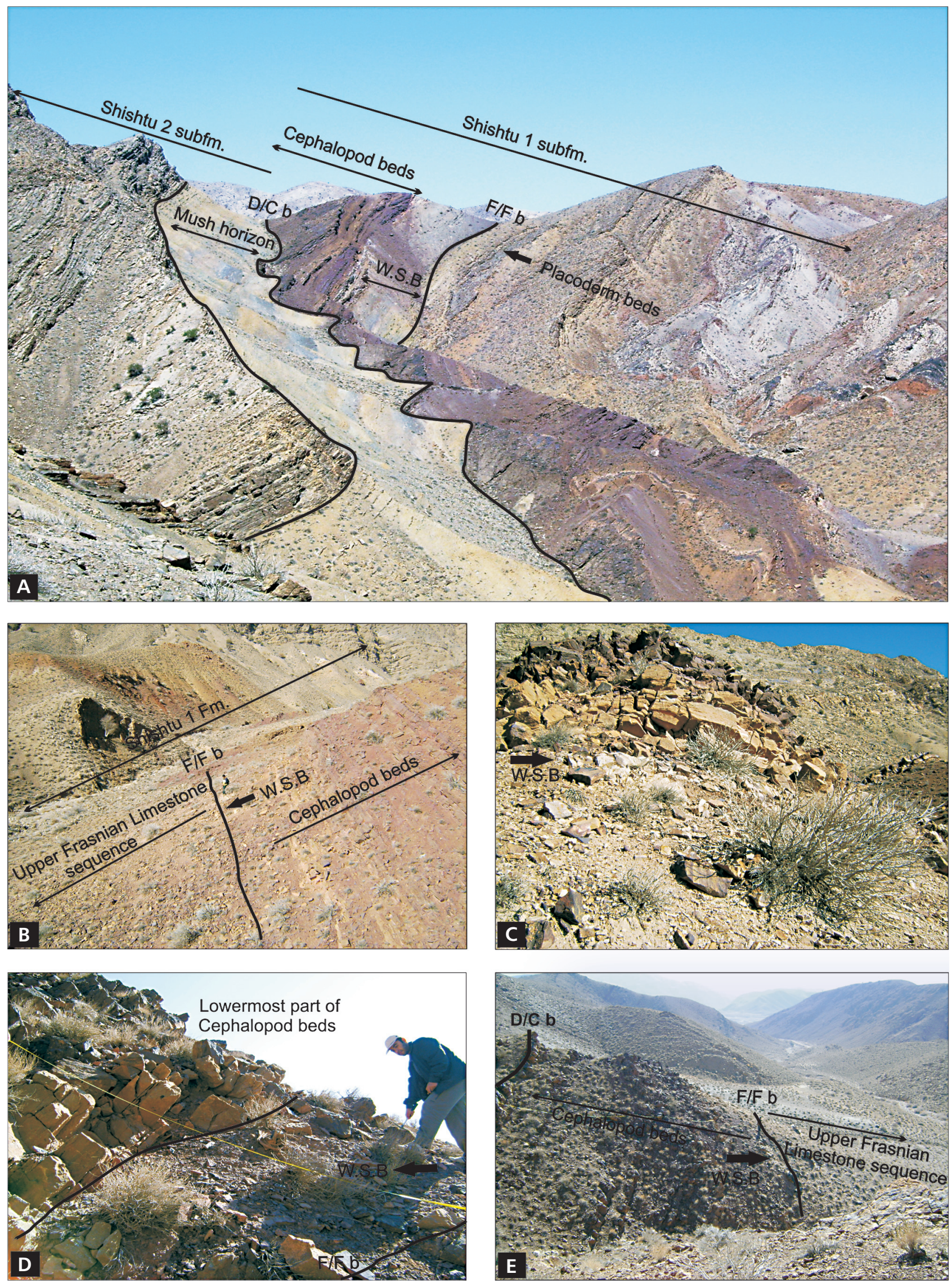
Ghale-kalaghu section

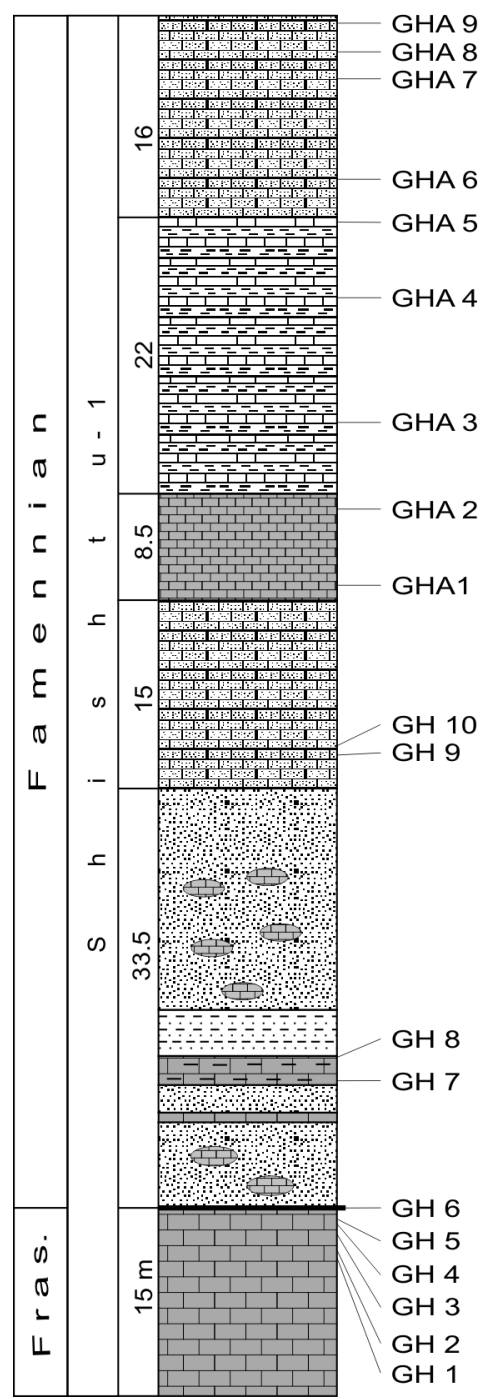

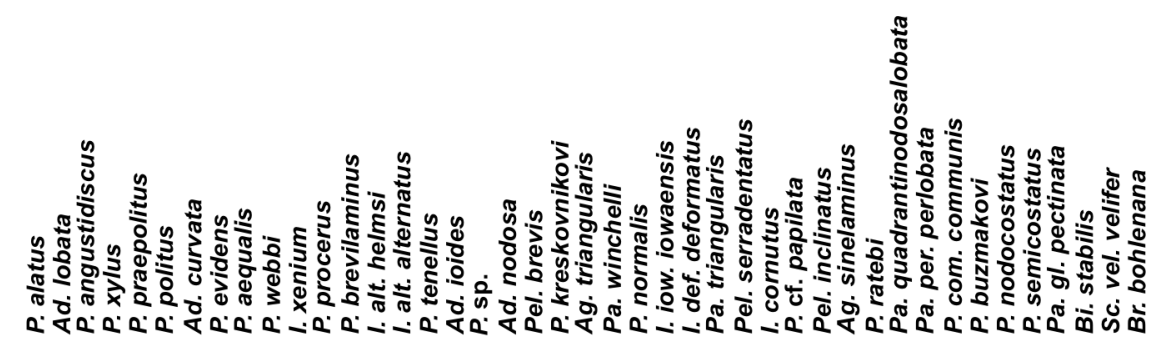

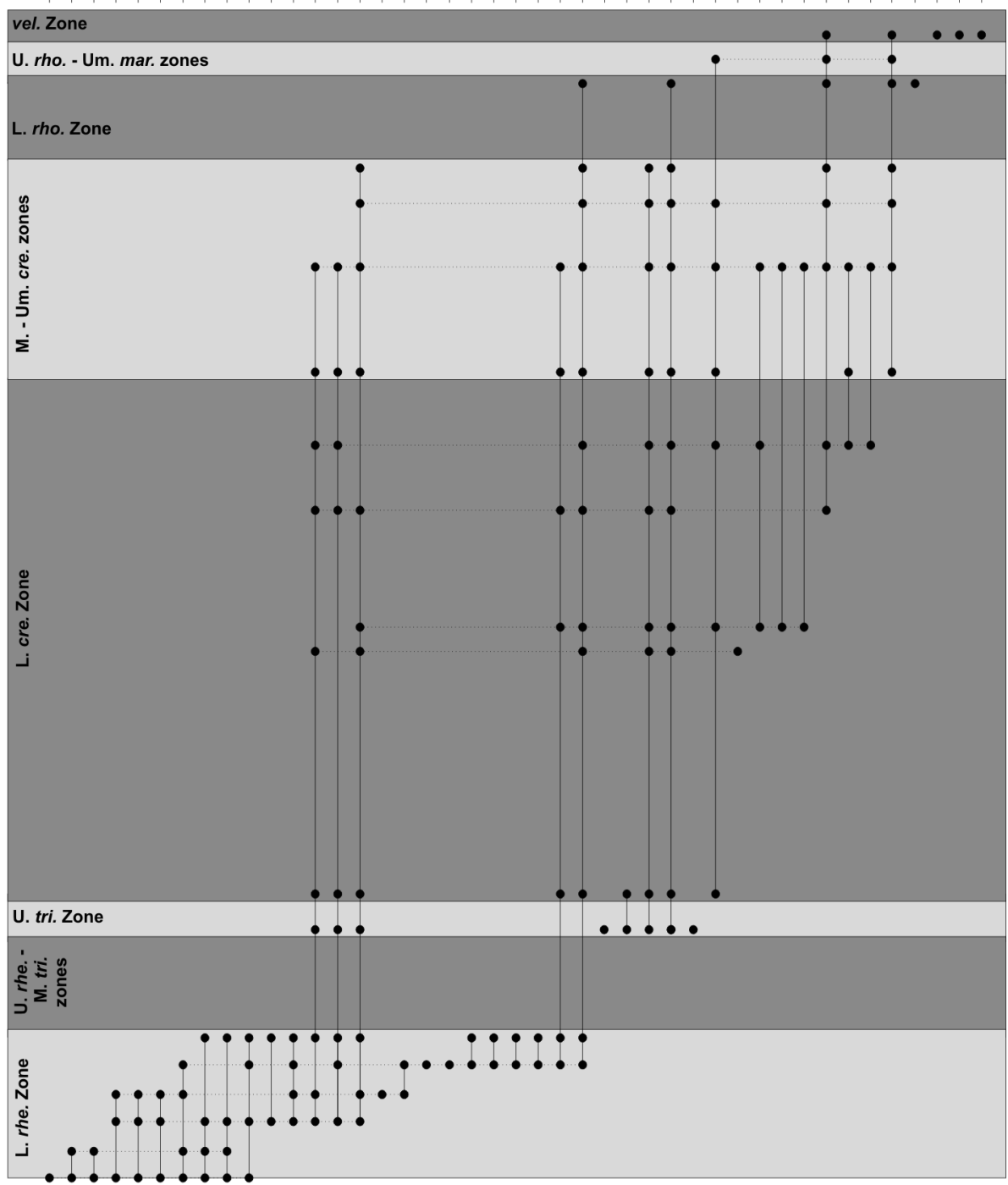

Figure 4. Conodont occurrences and biozonation of the Ghale-kalaghu section. Abbreviations: Ad. - Ancyrodella, Ag. - Ancyrognathus, Bi. - Bispathodus, I. - Icriodus, Pal. - Palmatolepis, Pel. - Pelekysgnathus, P. - Polygnathus, Sc. - Scaphignathus, L. rhe. - Lower rhenana, M. tri. - Middle triangularis, U. tri. - Upper triangularis, L. cre. - Lower crepida, M.-Um. cre. - Middle to Uppermost crepida, L. rho. - Lower rhomboidea, U. rho. - Upper rhomboidea, U. mar. - Upper marginifera, vel. - velifer.

\section{Howz-e-dorah 2 section}

The Howz-e-dorah 2 section (Figs 1, 2, 3b, d, 6) is located close to section Howz-e-dorah 1 in the same flank of the hill, at coordinates: base $33^{\circ} 22^{\prime} 16.67^{\prime \prime} \mathrm{N}-57^{\circ} 20^{\prime} 23^{\prime \prime} \mathrm{E}$ and top: $33^{\circ} 22^{\prime} 26.24^{\prime \prime} \mathrm{N}-57^{\circ} 20^{\prime} 25.48^{\prime \prime} \mathrm{E}$.
The Howz-e-dorah 2 section was measured across the Frasnian/Famennian boundary. It includes $15 \mathrm{~m}$ of the uppermost Frasnian limestone, $13.7 \mathrm{~m}$ of white to brown sandstone, and $9 \mathrm{~m}$ of sandy oolitic limestone, which represents the lowermost part of the "Cephalopod bed". 
Table 1. Range chart of conodont species in the Ghale-kalaghu section. For abbreviation of conodont genera see the caption of Fig. 4.

\begin{tabular}{|c|c|c|c|c|c|c|c|c|c|c|c|c|c|c|c|c|c|c|c|c|}
\hline GHALE-KALAGHU & $\begin{array}{c}\mathrm{GH} \\
1\end{array}$ & $\begin{array}{c}\mathrm{GH} \\
2\end{array}$ & $\begin{array}{c}\mathrm{GH} \\
3\end{array}$ & $\begin{array}{c}\mathrm{GH} \\
4\end{array}$ & $\begin{array}{c}\mathrm{GH} \\
5\end{array}$ & $\begin{array}{c}\mathrm{GH} \\
6\end{array}$ & $\begin{array}{c}\mathrm{GH} \\
7\end{array}$ & $\begin{array}{c}\mathrm{GH} \\
8\end{array}$ & $\begin{array}{c}\mathrm{GH} \\
9\end{array}$ & $\begin{array}{l}\text { GH } \\
10\end{array}$ & $\begin{array}{c}\text { GHA } \\
1\end{array}$ & $\begin{array}{c}\text { GHA } \\
2\end{array}$ & $\begin{array}{c}\mathrm{AHA} \\
3\end{array}$ & $\begin{array}{c}\text { GHA } \\
4\end{array}$ & $\begin{array}{c}\text { GHA } \\
5\end{array}$ & $\begin{array}{c}\text { GHA } \\
6\end{array}$ & $\begin{array}{c}\mathrm{GHA} \\
7\end{array}$ & $\begin{array}{c}\text { GHA } \\
8\end{array}$ & $\begin{array}{c}\mathrm{GHA} \\
9\end{array}$ & $\Sigma$ \\
\hline Ad. curvata & 1 & 2 & & 1 & 1 & & & & & & & & & & & & & & & 5 \\
\hline Ad. ioides & & & & 2 & 1 & & & & & & & & & & & & & & & 3 \\
\hline Ad. lobata & 1 & 1 & & & & & & & & & & & & & & & & & & 2 \\
\hline Ad. nodosa & & & & & 1 & & & & & & & & & & & & & & & 1 \\
\hline Ag. sinelaminus & & & & & & & & & 1 & & & & & & & & & & & 1 \\
\hline Ag. triangularis & & & & & 3 & 2 & & & & & & & & & & & & & & 5 \\
\hline Bi. bohlenana & & & & & & & & & & & & & & & & & & & 1 & 1 \\
\hline Bi. stabilis & & & & & & & & & & & & & & & & & & & 2 & 2 \\
\hline I. al. alternatus & & & 3 & 5 & & 6 & 15 & 3 & 16 & 5 & 11 & & 5 & 22 & 9 & 2 & & & & 102 \\
\hline I. al. helmsi & & & 5 & & 3 & 1 & 3 & 2 & & & 3 & 1 & 3 & 11 & & & & & & 32 \\
\hline I. cornutus & & & & & & & 7 & 6 & 8 & 13 & 17 & 5 & 10 & 6 & 7 & 4 & 17 & & & 100 \\
\hline I. def. deformatus & & & & & & & 1 & & & & & & & & & & & & & 1 \\
\hline I. iow. iowaensis & & & & & 7 & 15 & 1 & 12 & 11 & 6 & 27 & 5 & 2 & 9 & 22 & 10 & 12 & & & 139 \\
\hline I. xenium & & & 1 & & & 2 & & & & & & & & & & & & & & 3 \\
\hline P. aequalis & 3 & 2 & 2 & & & 1 & & & & & & & & & & & & & & 8 \\
\hline P. alatus & 1 & & & & & & & & & & & & & & & & & & & 1 \\
\hline P. angustidiscus & 2 & 1 & & & & & & & & & & & & & & & & & & 3 \\
\hline P. brevilaminus & & & 3 & 2 & & 3 & 1 & 2 & 3 & & 1 & 5 & 3 & 1 & & & & & & 24 \\
\hline P. buzmakovi & & & & & & & & & & & & 3 & 2 & 1 & & & & & & 6 \\
\hline$P$. cf. papilata & & & & & & & 1 & & & & & & & & & & & & & 1 \\
\hline P. com. communis & & & & & & & & & & & 5 & 3 & & 2 & 7 & 4 & 2 & 8 & 2 & 33 \\
\hline P. evidens & 1 & 1 & 1 & & & 2 & & & & & & & & & & & & & & 5 \\
\hline P. kreskovnikovi & & & & & 1 & 1 & & & & & & & & & & & & & & 2 \\
\hline P. nodocostatus & & & & & & & & & & & & 1 & & 1 & & & & & & 2 \\
\hline P. normalis & & & & & 1 & 2 & & 1 & & 2 & 1 & & 2 & 3 & & & & & & 12 \\
\hline$P$. politus & 1 & & 5 & 3 & & & & & & & & & & & & & & & & 9 \\
\hline P. praepolitus & 2 & & 1 & 2 & & & & & & & & & & & & & & & & 5 \\
\hline$P$. procerus & 1 & & 1 & 1 & 2 & 2 & & & & & & & & & & & & & & 7 \\
\hline P. ratebi & & & & & & & & & & 2 & & 1 & & 1 & & & & & & 4 \\
\hline P. semicostatus & & & & & & & & & & & & & 15 & 17 & 12 & 26 & 48 & 11 & 19 & 148 \\
\hline P. tenellus & & & & 1 & & & & & & & & & & & & & & & & 1 \\
\hline P. webbi & 8 & & 7 & & 7 & 12 & & & & & & & & & & & & & & 34 \\
\hline P. xylus & 2 & & 2 & 1 & & & & & & & & & & & & & & & & 5 \\
\hline P. sp. & & & & & 1 & & & & & & & & & & & & & & & 1 \\
\hline Pa. gl. pectinata & & & & & & & & & & & & & & & & & 1 & & & 1 \\
\hline Pa. per. perlobata & & & & & & & & & & 2 & & & & 2 & & & & & & 4 \\
\hline Pa. qudrantinodosalobata & & & & & & & & & & 1 & & & & 1 & & & & & & 2 \\
\hline Pa. triangularis & & & & & & & 3 & 2 & & & & & & & & & & & & 5 \\
\hline Pa. winchelli & & & & & 1 & 1 & & & & & & & & & & & & & & 2 \\
\hline Pel. brevis & & & & & 1 & 1 & & & & & & & & & & & & & & 2 \\
\hline Pel. inclinatus & & & & & & & & 2 & & 2 & & 1 & 2 & 3 & 2 & & & 2 & & 14 \\
\hline Pel. serradentatus & & & & & & & 3 & 7 & 5 & 2 & 1 & 1 & 5 & 1 & 4 & 3 & & & & 32 \\
\hline Sc. vel. velifer & & & & & & & & & & & & & & & & & & & 17 & 17 \\
\hline Unassigned elements & 18 & 11 & 8 & 27 & 19 & 54 & 5 & 29 & 42 & 8 & 35 & 8 & 58 & 68 & 95 & 61 & 23 & 41 & 14 & 624 \\
\hline TOTAL & 41 & 18 & 39 & 45 & 49 & 105 & 40 & 66 & 86 & 43 & 101 & 34 & 107 & 149 & 158 & 110 & 103 & 62 & 55 & 1411 \\
\hline
\end{tabular}


Table 2. Range chart of conodont species in the Howz-e-dorah 1 section. For abbreviation of conodont genera see the caption of Fig. 4.

\begin{tabular}{|c|c|c|c|c|c|c|c|c|c|c|c|c|c|c|c|c|c|c|}
\hline HOWZ-E-DORAH 1 & $\begin{array}{c}\text { HAD } \\
1 \\
\end{array}$ & $\begin{array}{c}\text { HDA } \\
2 \\
\end{array}$ & $\begin{array}{c}\text { HDA } \\
3 \\
\end{array}$ & $\begin{array}{c}\text { HDA } \\
4 \\
\end{array}$ & $\begin{array}{c}\text { HDA } \\
5 \\
\end{array}$ & $\begin{array}{c}\text { HDA } \\
6 \\
\end{array}$ & $\begin{array}{c}\text { HDA } \\
7 \\
\end{array}$ & $\begin{array}{c}\text { HDA } \\
8 \\
\end{array}$ & $\begin{array}{c}\text { HDA } \\
9 \\
\end{array}$ & $\begin{array}{c}\text { HDA } \\
10 \\
\end{array}$ & $\begin{array}{c}\text { HDA } \\
11 \\
\end{array}$ & $\begin{array}{c}\text { HDA } \\
12 \\
\end{array}$ & $\begin{array}{c}\text { HDA } \\
13 \\
\end{array}$ & $\begin{array}{c}\text { HDA } \\
14 \\
\end{array}$ & $\begin{array}{c}\text { HDA } \\
15 \\
\end{array}$ & $\begin{array}{c}\text { HDA } \\
16 \\
\end{array}$ & $\begin{array}{c}\text { HDA } \\
17 \\
\end{array}$ & $\Sigma$ \\
\hline Ad. curvata & 1 & 3 & & & 1 & & & & & & & & & & & & & 5 \\
\hline Ad. ioides & & & 2 & 3 & 2 & & & & & & & & & & & & & 7 \\
\hline Ad. lobata & 1 & & & & & & & & & & & & & & & & & 1 \\
\hline Ad. nodosa & & & & 1 & 1 & & & & & & & & & & & & & 2 \\
\hline Ag. sinelaminus & & & & & & & & & & 1 & & & & & & & & 1 \\
\hline Ag. triangularis & & & & 7 & 3 & & & & & & & & & & & & & 10 \\
\hline I. al. alternatus & & 7 & 12 & & & 19 & & 41 & 13 & & & 7 & & 23 & & 12 & & 134 \\
\hline I. al. helmsi & & 5 & & & 3 & & 5 & & & & 2 & 1 & 2 & 8 & & & & 26 \\
\hline I. cornutus & & & & & & 11 & 16 & 24 & 27 & & & & 12 & & & 27 & 31 & 148 \\
\hline I. def. deformatus & & & & & & 4 & & & & & & & & & & & & 4 \\
\hline I. iow. iowaensis & & & & & & & & & 18 & 7 & & 14 & & & 23 & 8 & 29 & 99 \\
\hline I. xenium & & 2 & & & 2 & & & & & & & & & & & & & 4 \\
\hline P. aequalis & 4 & 3 & 7 & & 3 & & & & & & & & & & & & & 17 \\
\hline P. alatus & 1 & & & & & & & & & & & & & & & & & 1 \\
\hline P. angustidiscus & 2 & 1 & & & & & & & & & & & & & & & & 3 \\
\hline P. brevilaminus & & 2 & 2 & 5 & 2 & 1 & 5 & 4 & 1 & & & 3 & 1 & 4 & & & & 30 \\
\hline P. buzmakovi & & & & & & & & & & & & & 2 & 1 & & & & 3 \\
\hline P. com. communis & & & & & & & & & & & & 5 & & 7 & & 3 & 7 & 22 \\
\hline P. evidens & 2 & 1 & & & 2 & & & & & & & & & & & & & 5 \\
\hline P. kreskovnikovi & & & & 1 & 1 & & & & & & & & & & & & & 2 \\
\hline P. normalis & & & & 2 & 3 & & 3 & & & 1 & 2 & 1 & 2 & 1 & & & & 15 \\
\hline$P$. politus & & 3 & & 8 & & & & & & & & & & & & & & 11 \\
\hline$P$. praepolitus & 1 & & 2 & & & & & & & & & & & & & & & 3 \\
\hline P. procerus & & & & 1 & & & & & & & & & & & & & & 1 \\
\hline P. ratebi & & & & & & & & & & 2 & & & & 1 & & & & 3 \\
\hline P. semicostatus & & & & & & & & & & & & & & 18 & 43 & 12 & 5 & 78 \\
\hline P. tenellus & & & & 1 & & & & & & & & & & & & & & 1 \\
\hline P. webbi & 16 & 9 & 32 & & 14 & & & & & & & & & & & & & 71 \\
\hline P. xylus & 1 & 2 & 1 & & & & & & & & & & & & & & & 4 \\
\hline Pa. gl. pectinata & & & & & & & & & & & & & & & & & 1 & 1 \\
\hline Pa.per. perlobata & & & & & & & & & & & & & & & 2 & 1 & & 3 \\
\hline Pa. qudrantinodosalobata & & & & & & & & & & & & 1 & & & & & & 1 \\
\hline Pa. triangularis & & & & & & 3 & 3 & & & 1 & & & & 1 & & & & 8 \\
\hline Pa. winchelli & & & & 1 & 1 & & & & & & & & & & & & & 2 \\
\hline Pel. brevis & & & & 1 & 1 & & & & & & & & & & & & & 2 \\
\hline Pel. inclinatus & & & & & & & & & & 4 & 1 & 2 & & & & & & 7 \\
\hline Pel. serradentatus & & & & & & 7 & & & 4 & & 5 & & & & & 3 & & 19 \\
\hline Unassigned elements & 87 & 34 & 28 & 16 & 69 & 11 & 37 & 89 & 24 & 45 & 8 & 13 & 5 & 43 & 64 & 5 & 38 & 616 \\
\hline TOTAL & 116 & 72 & 86 & 47 & 108 & 56 & 69 & 158 & 87 & 61 & 18 & 47 & 24 & 107 & 132 & 71 & 111 & 1370 \\
\hline
\end{tabular}

\section{Conodont data}

Forty-seven conodont samples (3-4 kg each) were collected: 19 samples from the Ghale-kalaghu section, 17 samples from the Howz-e-dorah 1 section, and 11 samples from the Howz-e-dorah 2 section. The samples were pro- cessed with the conventional acetic and/or formic acid technique. All samples yielded conodonts varying in abundance and state of preservation.

About 2400 conodont elements were collected (Tables 1, 2, 3). Conodonts are not abundant, only a few samples yielded more than a dozen elements $/ \mathrm{kg}$; in general 
Table 3. Range chart of conodont species in the Howz-e-dorah 2 section. For abbreviation of conodont genera see the caption of Fig. 4.

\begin{tabular}{|c|c|c|c|c|c|c|c|c|c|c|c|c|}
\hline HOWZ-E-DORAH 2 & HBA1 & HBA2 & HBA3 & HBA4 & HBA5 & HBA6 & HBA7 & HBA8 & HBA9 & HBA10 & HBA11 & TOTAL \\
\hline Ad. curvata & 2 & 1 & 1 & & & 1 & & & & & & 5 \\
\hline Ad. ioides & & & & 2 & 1 & 1 & & & & & & 4 \\
\hline Ad. lobata & 1 & 1 & & & & & & & & & & 2 \\
\hline Ad. nodosa & & & & & 1 & 1 & & & & & & 2 \\
\hline Ag. triangularis & & & & & 3 & 3 & & & & & & 6 \\
\hline I. al. alternatus & & & 3 & 8 & & & 7 & & 14 & & 9 & 41 \\
\hline I. al. helmsi & & & 2 & & & 5 & & 2 & & 2 & 3 & 14 \\
\hline I. cornutus & & & & & & & 9 & 9 & 19 & 28 & & 65 \\
\hline I. def. deformatus & & & & & & & 1 & & & & & 1 \\
\hline I. iow. iowaensis & & & & & & & 9 & 5 & 19 & & 8 & 41 \\
\hline I. xenium & & & 2 & 1 & 1 & 1 & & & & & & 5 \\
\hline P. aequalis & 3 & 5 & & & & & & & & & & 8 \\
\hline P. alatus & 1 & 1 & & & & & & & & & & 2 \\
\hline P. angustidiscus & 2 & 2 & 1 & & & & & & & & & 5 \\
\hline P. brevilaminus & & & 2 & 1 & 1 & 2 & 1 & 3 & 1 & & 1 & 12 \\
\hline P. buzmakovi & & & & & & & & & & 2 & 1 & 3 \\
\hline P. com. communis & & & & & & & & & & & 7 & 7 \\
\hline P. evidens & 2 & 1 & 2 & & & 2 & & & & & & 7 \\
\hline P. normalis & & & & & 1 & 2 & & 2 & & 2 & 1 & 8 \\
\hline P. politus & & & 8 & & 4 & & & & & & & 12 \\
\hline P. praepolitus & 1 & 1 & & 1 & & & & & & & & 3 \\
\hline P. procerus & & & & & 1 & & & & & & & 1 \\
\hline P. tenellus & & & & & 1 & & & & & & & 1 \\
\hline P. semicostatus & & & & & & & & & & & 9 & 9 \\
\hline$P$. sp. A & & & & & & & & & 1 & & & 1 \\
\hline$P$. sp. B & & & & & & & & & & & 2 & 2 \\
\hline P. webbi & 9 & 14 & 11 & 24 & & 12 & & & & & & 70 \\
\hline P. xylus & 1 & 2 & 1 & 2 & & & & & & & & 6 \\
\hline Pa. triangularis & & & & & & & 2 & 1 & & & & 3 \\
\hline Pa. winchelli & & & & & 1 & 1 & & & & & & 2 \\
\hline Pel. brevis & & & & & 1 & 1 & & & & & & 2 \\
\hline Pel. inclinatus & & & & & & & & 2 & & & & 2 \\
\hline Pel. serradentatus & & & & & & & 5 & & 3 & & & 8 \\
\hline Unassigned elements & 43 & 12 & 27 & 5 & 27 & 13 & 37 & 12 & 39 & 18 & 16 & 249 \\
\hline TOTAL & 65 & 40 & 60 & 44 & 43 & 45 & 71 & 36 & 96 & 52 & 57 & 609 \\
\hline
\end{tabular}

higher yields occurred in the upper part of the studied interval.

The state of preservation of the conodonts is generally excellent in the upper Frasnian, where many specimens are complete without contamination. In the lower Famennian the preservation is good, but some specimens are broken and/or coated by an iron hematite crust. The color of conodonts is dark black (C.A.I. 5) in the upper Frasnian, then gradually turns to brown (C.A.I. 3) in the upper part of the sections.

Forty-five species and subspecies belonging to eight genera: Ancyrodella, Ancyrognathus, Bispathodus, Icriodus, Polygnathus, Palmatolepis, Pelekysgnathus and Scaphignathus were discriminated (Tables 1,2,3). The association is dominated by the shallow water genera Icriodus and Polygnathus; palmatolepids are scarce in all sampled horizons.

The collection is stored in the Department of Geology of the Isfahan University under acronym EUIC. Repository numbers of the figured specimens (Figs 7, 8, 9) can be obtained from the figures captions. 


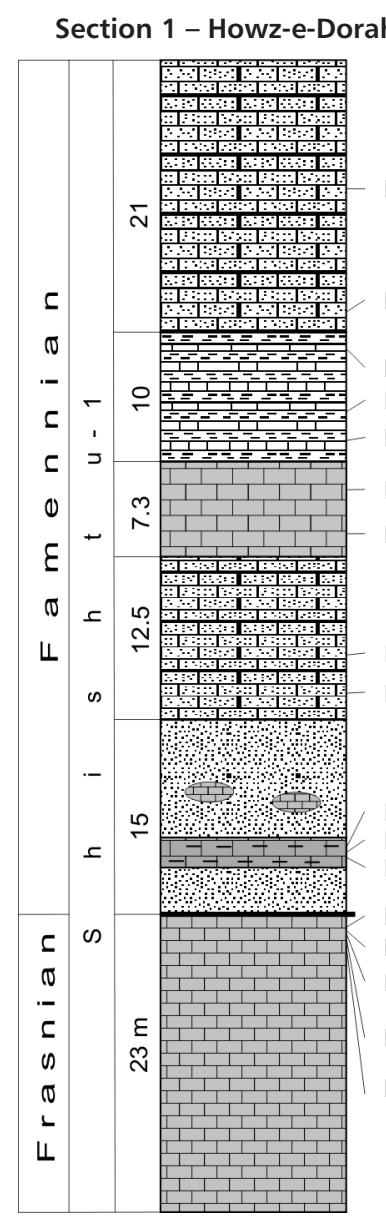

\section{Biostratigraphy}

The "Late Devonian standard conodont zonation" (Ziegler \& Sandberg 1990) is one of two widely used conodont zonation schemes in use in the Late Devonian. It is based on pelagic index species, mainly of the genus Palmatolepis that are rare in the relatively shallow water sediments of the Tabas area. Therefore we also utilize icriodids and polygnathids to identify the zonal boundaries. As a result, it is not possible to recognize all the zones, but sometimes only longer biostratigraphic intervals that group some adjacent zones.

Eight biointervals, from late Frasnian to middle Famennian were discriminated.

\section{Lower rhenana Zone}

The Lower rhenana Zone is discriminated in the limestone unit at the base of the sections (GH 1-6, HDA 1-5, HBA 1-6) by the co-occurrence of Polygnathus aequalis,
$P$. praepolitus, and $P$. politus. The first two species became extinct within this interval (Ji \& Ziegler 1993, Ovnatanova $\&$ Kononova 2001), while $P$. politus enters within this zone (Ovnatanova \& Kononova 2001). This interval is characterized by an abundant and well-preserved conodont fauna, and its top is marked by the unconformity between the limestone and the sandstone units.

\section{Upper rhenana-Middle triangularis zones}

This interval has not been documented, due to the lack of recovered fauna and the unconformity between the limestone and the sandstone units.

\section{Upper triangularis Zone}

The Upper triangularis Zone is identified in the lower part of the mainly sandy unit (samples GH 7, HDA 6-10, 

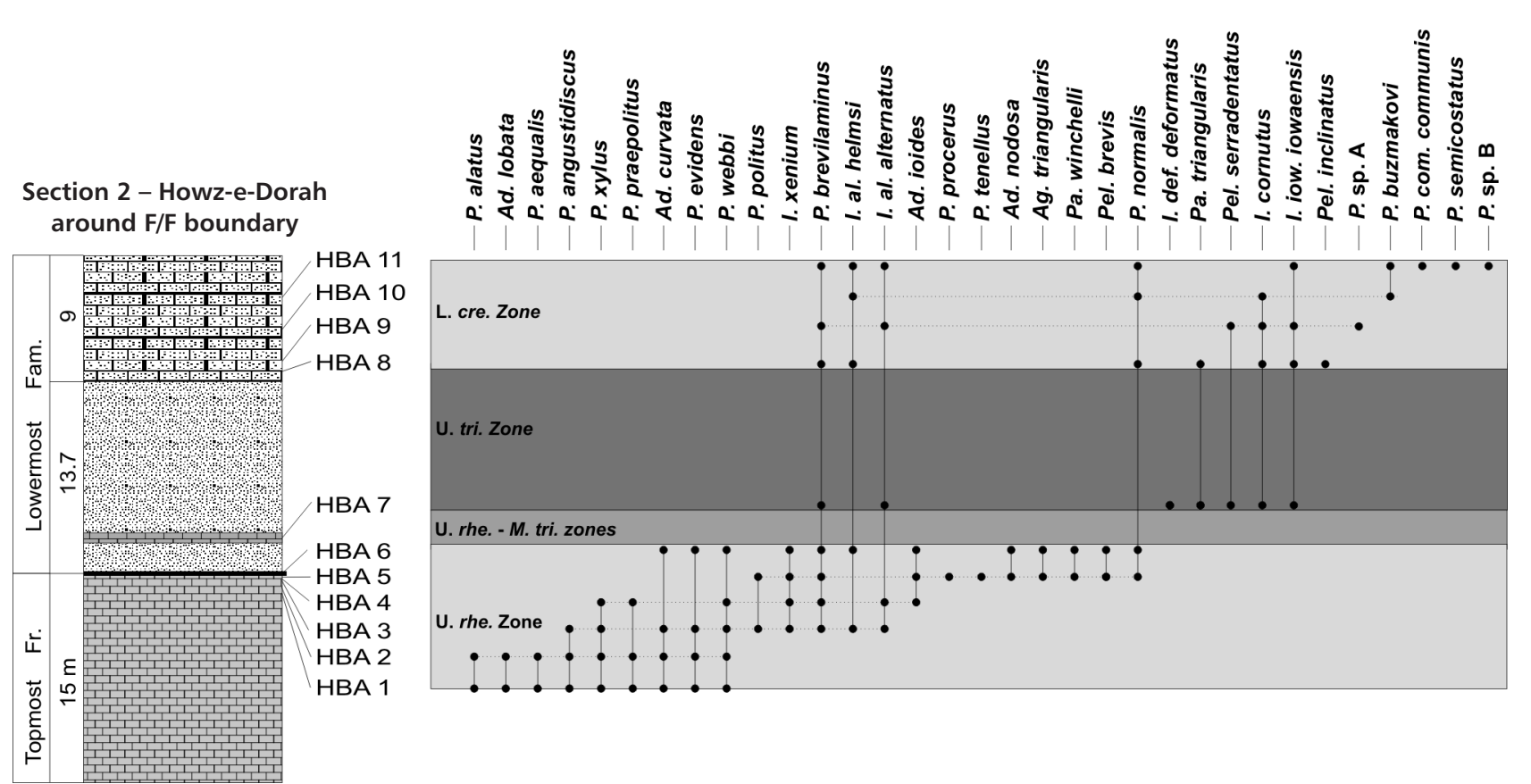

Figure 6. Conodont occurrences and biozonation of the Howz-e-dorah 2 section. For abbreviation see the caption of Fig. 4.

HBA 7) by the occurrence of Icriodus cornutus, which, according to Bultynck (2003) has its first appearance datum within this zone. The upper boundary is marked by the first occurrence of Pelekysgnathus inclinatus. Icriodids are dominant in this interval; polygnathids are also common.

\section{Lower crepida Zone}

The lower crepida Zone is discriminated in samples GH 8-GHA 3, HDA 11-13 and HBA 8-11. The entrance of Pelekysgnathus inclinatus, which has its FAD at the base of the Lower crepida Zone (Sandberg \& Dreesen 1984, Bultynck 2003), allows recognition of the lower boundary. The upper boundary is marked by the first occurrence of Polygnathus semicostatus. Icriodids are dominant in this interval.

\section{Middle-uppermost crepida zones}

An undifferentiated interval is discriminated in the Ghale-kalaghu (samples GH 4-6) and Howz-e-dorah 1 (samples HD 14-16) sections. The lower boundary is recognized by the first occurrence of Polygnathus semicostatus, which ranges from the Middle crepida to the Upper $e x$ pansa zones (Ji \& Ziegler 1993). The upper limit is identified by the last occurrence of Icriodus alt. alternatus, which ranges from the Lower rhenana to the Uppermost crepida Zone (Bultynck 2003).

\section{Lower rhomboidea Zone}

The Lower rhomboidea Zone is recognized in the upper part of the Ghale-kalaghu (sample GHA 7) and Howz-e-dorah 1 (samples HD 17) sections, as the interval between the last occurrence of Icriodus alt. alternatus and the last occurrence of I. iow. iowaensis, that became extinct at the top of this zone (Bultynck 2003).

\section{Upper rhomboidea to Upper marginifera zones}

A thin interval corresponding to an undifferentiated Upper rhomboidea to Upper marginifera zones is discriminated in the upper part of the Ghale-kalaghu section, as the interval between the last occurrence of I. iow. iowaensis and the first occurrence of Scaphignathus vel. velifer. Polygnathus semicostatus and Po. c. communis are dominant in this interval.

\section{velifer Zone}

This zone is identified at the top of the Ghale-kalaghu section by the entrance of Scaphignathus vel. velifer in sample GHA 9. This zone is equivalent to the Uppermost marginifera Zone by Ziegler \& Sandberg (1984) and named after the nominate taxon by Corradini (2008). Bispathodus stabilis and Branmehla bohlenana enter in this interval. 


\section{Systematic palaeontology}

Since most of the taxa collected in the Howz-e-dorah 1, Howz-e-dorah 2 and Ghale-kalaghu sections are well known in literature, systematic notes are restricted to necessary taxonomic and/or biostratigraphic remarks. Taxonomy is focused only on P1 elements. For suprageneric classification, the scheme proposed by Sweet (1988) is followed.

Class Conodonta Pander, 1856

Order Ozarkodinida Dzik, 1976

Family Cavusgnathidae Austin \& Rhodes, 1981

\section{Genus Scaphignathus Helms, 1959}

Type species. - Scaphignathus velifera Helms, 1959.

\section{Scaphignathus velifer velifer Helms, 1959 Figure 9KK}

1959 Scaphignathus velifera Ziegler (sic); Helms, p. 655, pl. 2, fig. 19; pl. 5, figs 20, 28.

1971 Scaphignathus velifer Helms. - Beinert et al., p. 83, pl. 2, figs 1-6, 8, 9, 11 (cum syn.).

1984 Scaphignathus velifer velifer Helms. - Ziegler \& Sandberg, p. 188.

2003 Scaphignathus velifer velifer Helms. - Corradini, pp. 76,77 , pl. 10, fig. 7 .

Studied material. - 17 specimens from the upper part of the Ghale-kalaghu section.
Remarks. - According to Ziegler \& Sandberg (1984), representatives of Sc. velifer velifer have a well-developed trough in the anterior part of the platform and a blade on the right side, but rare specimens may have a central blade.

All the studied specimens have an evident short trough in the anterior part of the platform, small nodes aligned in the posterior part, the free blade attached on the right side of the platform; in lateral view the platform is slightly arched to nearly flat, and the free blade is very high.

Stratigraphic range. - From the velifer Zone (= Uppermost marginifera Zone of Ziegler \& Sandberg, 1984) to the Upper trachytera Zone (Ziegler \& Sandberg 1984).

Family Polygnathidae Bassler, 1925

\section{Genus Polygnathus Hinde, 1879}

Type species. - Polygnathus dubius Hinde, 1879.

\section{Polygnathus ratebi Yazdi, 1999}

Figure 8II, AAA

1999 Polygnathus ratebi; Yazdi; pp. 197, 198, pl. 9, figs $1-5$.

Material. -7 specimens.

Remarks. - Polygnathus ratebi is characterized by a carina limited to the anterior part of the platform, deep adcarinal troughs and posterior part of the platform are covered by

Figure 7. Conodonts from the Ghale-kalaghu, Howz-e-dorah 1 and 2 sections. $\bullet A-E-$ Palmatolepis triangularis Sannemann, $1955 \mathrm{~b}$; A - upper view of EUIC 10001, sample GH 7 (Upper triangularis Zone), B - upper view of EUIC 10002, sample GH 8 (Lower crepida Zone), C - upper view of EUIC 10003, sample HDA 6 (Upper triangularis Zone), D - upper view of EUIC 10004, sample HDA 10 (Lower crepida Zone), E - upper view of EUIC 10005, sample HBA 8 (Lower crepida Zone). • F, J - Palmatolepis perlobata perlobata Ziegler, 1960; F - upper view of EUIC 10006, sample GH 10 (Lower crepida Zone), J - upper view of EUIC 10007, sample GHA 4 (Middle to Uppermost crepida zones). $\bullet \mathrm{G}, \mathrm{H}-$ Palmatolepis winchelli (Stauffer, 1938); G - upper view of EUIC 10008, sample GH 6 (Lower rhenana Zone), H - upper view of EUIC 10009, sample HDA 4 (Lower rhenana Zone). - I - Palmatolepis glabra pectinata Ziegler, 1962; upper view of EUIC 10010, sample HDA 17 (Lower rhomboidea Zone). • K, L - Palmatolepis quadrantinodosalobata Sanneman, 1955b; K - upper view of EUIC 10011, sample HDA 14 (Middle to Uppermost crepida zones), L - upper view of EUIC 10012, sample GH 10 (Lower crepida Zone). M, O - Ancyrodella lobata (Branson \& Mehl, 1934) M2; M - upper view of EUIC 10013, sample GH 2 (Lower rhenana Zone), O - upper view of EUIC 10014, sample HDA 1 (Lower rhenana Zone). $-\mathrm{N}$, T - Ancyrodella curvata (Branson \& Mehl, 1934) M2; N - upper view of EUIC 10016, sample GH 2 (Lower rhenana Zone), T - upper view of EUIC 10015, sample HBA 1 (Lower rhenana Zone). - P-R - Ancyrodella ioides Ziegler, 1959; P - upper view of EUIC 10017, sample GH 4 (Lower rhenana Zone), Q - upper view of EUIC 10018, sample GH 5 (Lower rhenana Zone), R - upper view of EUIC 10019, sample HDA 4 (Lower rhenana Zone). • S - Ancyrodella nodosa Ulrich \& Bassler, 1926; upper view of EUIC 10020, sample HDA 5 (Lower rhenana Zone). $・$ U, V - Ancyrognathus triangularis Youngquist, 1945 ; U - upper view of EUIC 10021, sample GH 5 (Lower rhenana Zone), V - upper view of EUIC 10022, sample HDA 4 (Lower rhenana Zone). $・$ W - Ancyrognathus sinelaminus Branson \& Mehl, 1934; upper view of EUIC 10023, sample GH 9 (Lower crepida Zone). • Fig. X - Polygnathus cf. papilata Youngquist \& Peterson, 1947; upper view of EUIC 10024, sample GH 7 (Upper triangularis Zone). • Y - Polygnathus nodocostatus nodocostatus Branson \& Mehl, 1934 ; upper view of EUIC 10025, sample GHA 2 (Lower crepida Zone). • Z, AA, BB - Polygnathus angustidiscus Youngquist, 1945; Z - upper view of EUIC 10026, sample GH 2 (Lower rhenana Zone), AA - upper view of EUIC 10027, sample HDA 2 (Lower rhenana Zone), BB - upper view of EUIC 10028, sample HBA 2 (Lower rhenana Zone). • CC-FF - Polygnathus xylus Stauffer, 1938; CC - upper view of EUIC 10029, sample GH 3 (Lower rhenana Zone), DD - upper view of EUIC 10030, sample GH 4 (Lower rhenana Zone), EE - upper view of EUIC 10031, sample HDA 2 (Lower rhenana Zone), FF - upper view of EUIC 10032, sample HDA 3 (Lower rhenana Zone). $\bullet$ GG - Polygnathus sp. Upper view of EUIC 10034, sample GH 5 (Lower rhenana Zone). 

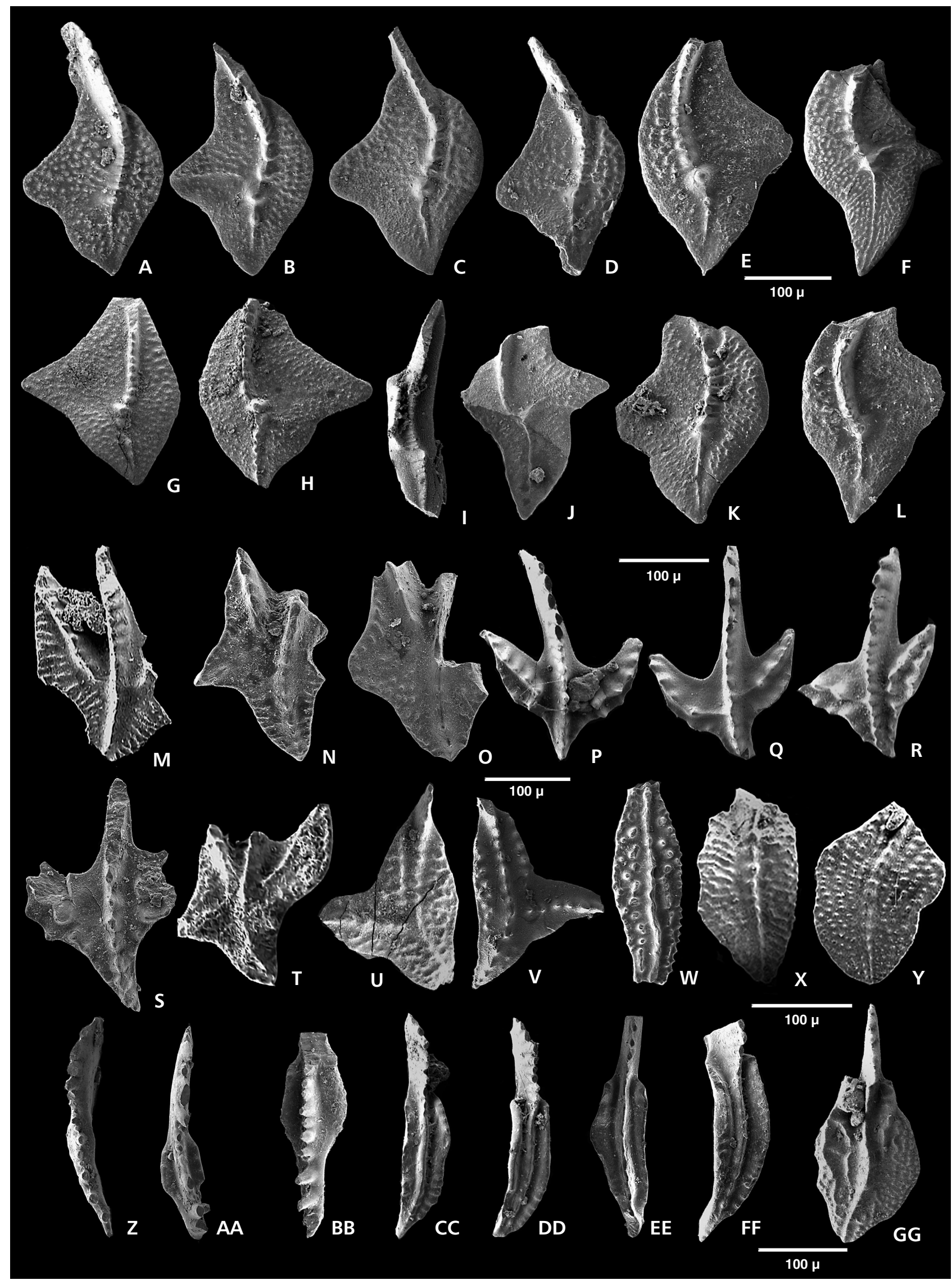
transverse ridges. Compared to the types figured by Yazdi (1999), our specimens are very similar and fit well in the description of the species, even if one specimen (Fig. 8II) has a more evident ornamentation on the anterior margins of the platform.

Stratigraphic range. - The species was reported from the Upper triangularis Zone to the Upper crepida Zone (Yazdi 1999). Our material suggests a possible occurrence up to the Uppermost crepida Zone.

\section{Polygnathus semicostatus Branson \& Mehl, 1934 Figure 9LL}

1934 Polygnathus semicostatus Branson \& Mehl; p. 247, pl. 21, figs 1, 2 .

1974 Polygnathus semicostatus Branson \& Mehl. - Dreesen \& Orchard, p. 3, pl. 1, figs 1-8, pl. 2, figs 1-25.

1975 Polygnathus semicostatus Branson \& Mehl. - Klapper in Ziegler (ed.), p. 317, pl. Polygnathus-5, fig. 6 (cum syn.).

Material. - 235 specimens.

Remarks. - P. semicostatus displays wide variability of morphological features. Dreesen \& Orchard (1974) recognized eight evolutionary morphological trends on the basis of increasing number of transversal ridges, progressive arching of the platform, and development of deep adcarinal grooves and a wide tongue. In the studied material the species shows a wide variability, and two morphotypes can be discriminated: some specimens have a narrow and elongate platform with strongly upturned margins and short ridges in the anterior part; others are wider in anterior part of the platform and narrow in the posterior part.

Range. - From the Middle crepida Zone to the Upper expansa Zone (Ji \& Ziegler 1993).

Family Spathognathodontidae Hass, 1959

\section{Genus Ancyrodella Ulrich \& Bassler, 1926}

Type species. - Ancyrodella nodosa Ulrich \& Bassler, 1926.

\section{Ancyrodella curvata (Branson \& Mehl, 1934)}

Figure $7 \mathrm{~N}, \mathrm{~T}$

1934a Ancyrognathus curvata; Branson \& Mehl, p. 241, pl. 19, figs 6,11 .

Figure 8. Conodonts from the Ghale-kalaghu, Howz-e-dorah 1 and 2 sections. • A-D - Polygnathus politus Ovnatanova, 1969; A - upper view of EUIC 10035, sample GH 1 (Lower rhenana Zone), B - upper view of EUIC 10036, sample GH 4 (Lower rhenana Zone), C - upper view of EUIC 10037, sample HDA 2 (Lower rhenana Zone), D - upper view of EUIC 10038, sample HDA 4 (Lower rhenana Zone). $\bullet \mathrm{E}-\mathrm{G}$ - Polygnathus praepolitus Kononova et al., 1996; E - upper view of EUIC 10039, sample GH 4 (Lower rhenana Zone), F - upper view of EUIC 10040, sample GH 4 (Lower rhenana Zone), $\mathrm{G}$ - upper view of EUIC 10041, sample HDA 1 (Lower rhenana Zone). $\bullet \mathrm{H}-\mathrm{K}, \mathrm{P}-$ Polygnathus communis communis Branson \& Mehl, 1934; $\mathrm{H}$ - upper and I - lower views of EUIC 10042, sample GHA 7 (Upper rhomboidea to Upper marginifera zones), J - upper view of EUIC 10043, sample HDA 17 (Lower rhomboidea Zone), K - upper view of EUIC 10044, sample GHA 8 (Upper rhomboidea to Upper marginifera zones), P - upper view of EUIC 10044, sample GHA 8 (Upper rhomboidea to Upper marginifera zones). $\bullet$ L-N - Polygnathus sp. B; L - upper view of EUIC 10045, sample HBA 11 (Lower crepida Zone), M - lower and upper (N) views of EUIC 10046, sample HBA 11 (Lower crepida Zone). $\bullet \mathrm{O}-$ Polygnathus. sp. A; upper view of EUIC 10047; sample HBA 9 (Lower crepida Zone). • Q-R, JJ - Polygnathus buzmakovi Kuzmin, 1990; Q - upper and lower (R) views of EUIC 10048, sample GHA 4 (Middle to Uppermost crepida zones), JJ - upper view of EUIC 10068, sample GHA 3 (Middle to Uppermost crepida zones). -S-U - Polygnathus evidens Klapper \& Lane, 1985; S - upper view of EUIC 10049, sample GH 1 (Lower rhenana Zone), T - upper and lower (U) views of EUIC 10050, sample GH 2 (Lower rhenana Zone). V-Y, KK, MM, NN - Polygnathus webbi Stauffer, 1938; V - upper view of EUIC 10051, sample GH 1 (Lower rhenana Zone), W - upper view of EUIC 10052, sample GH 5 (Lower rhenana Zone), X - upper view of EUIC 10053, sample GH 6 (Lower rhenana Zone), Y - upper view of EUIC 10054, sample HDA 1 (Lower rhenana Zone), KK - upper view of EUIC 10055, sample HDA 2 (Lower rhenana Zone), MM - upper view of EUIC 10056, sample HDA 3 (Lower rhenana Zone), NN - upper view of EUIC 10057, sample HBA 4 (Lower rhenana Zone). - Z-CC, LL - Polygnathus aequalis Klapper \& Lane, 1985; Z - upper view of EUIC 10058, sample HBA 1 (Lower rhenana Zone), AA - upper view of EUIC 10059, sample HBA 2 (Lower rhenana Zone), BB - upper view of EUIC 10060, sample HDA 2 (Lower rhenana Zone), CC - upper view of EUIC 10061, sample HDA 4 (Lower rhenana Zone), LL - upper view of EUIC 10062, sample HDA 5 (Lower rhenana Zone). EE - Polygnathus alatus Huddle, 1934; upper view of EUIC 10063, sample GH 1 (Lower rhenana Zone). FF, GG, PP, QQ - Polygnathus brevilaminus Branson \& Mehl, 1934; FF - upper view of EUIC 10064, sample GHA 1 (Lower crepida Zone), GG - upper view of EUIC 10065, sample GHA 4 (Middle to Uppermost crepida zones), PP - upper and lower (QQ) views of EUIC 10070, sample HDA 12 (Lower crepida Zone). HH, RR - Polygnathus tenellus Ji \& Ziegler, 1993; HH - upper view of EUIC 10066, sample HDA 4 (Lower rhenana Zone), RR - upper view of EUIC 10066, sample GH 5 (Lower rhenana Zone). - II, AAA - Polygnathus ratebi Yazdi, 1999; II - upper view of EUIC 10067, sample GH 9 (Lower crepida Zone), AAA - upper view of EUIC 10078, sample GHA 4 (Middle to Uppermost crepida zones). $\bullet$ OO - Polygnathus procerus Sannemann, 1955b; upper view of EUIC 10069, sample GH 4 (Lower rhenana Zone). SS, TT - Polygnathus sp.; upper (SS) and lower (TT) views of EUIC 10072, sample HBA 7 (Upper triangularis Zone). - UU, VV, XX - Bispathodus stabilis (Branson \& Mehl, 1934); upper (UU) and lower (VV) views of EUIC 10073, sample GHA 9 (velifer Zone), XX - lateral view of EUIC 10074, sample GHA 9 (velifer Zone). - WW - Branmehla bohlenana (Helms, 1959); upper view of EUIC 10075, sample GHA 9 (velifer Zone). $•$ YY, ZZ - Polygnathus krestovnikovi Ovnatanova, 1969; YY - upper view of EUIC 10076, sample HDA 2 (Lower rhenana Zone), ZZ - upper view of EUIC 10077, sample HDA 4 (Lower rhenana Zone). 

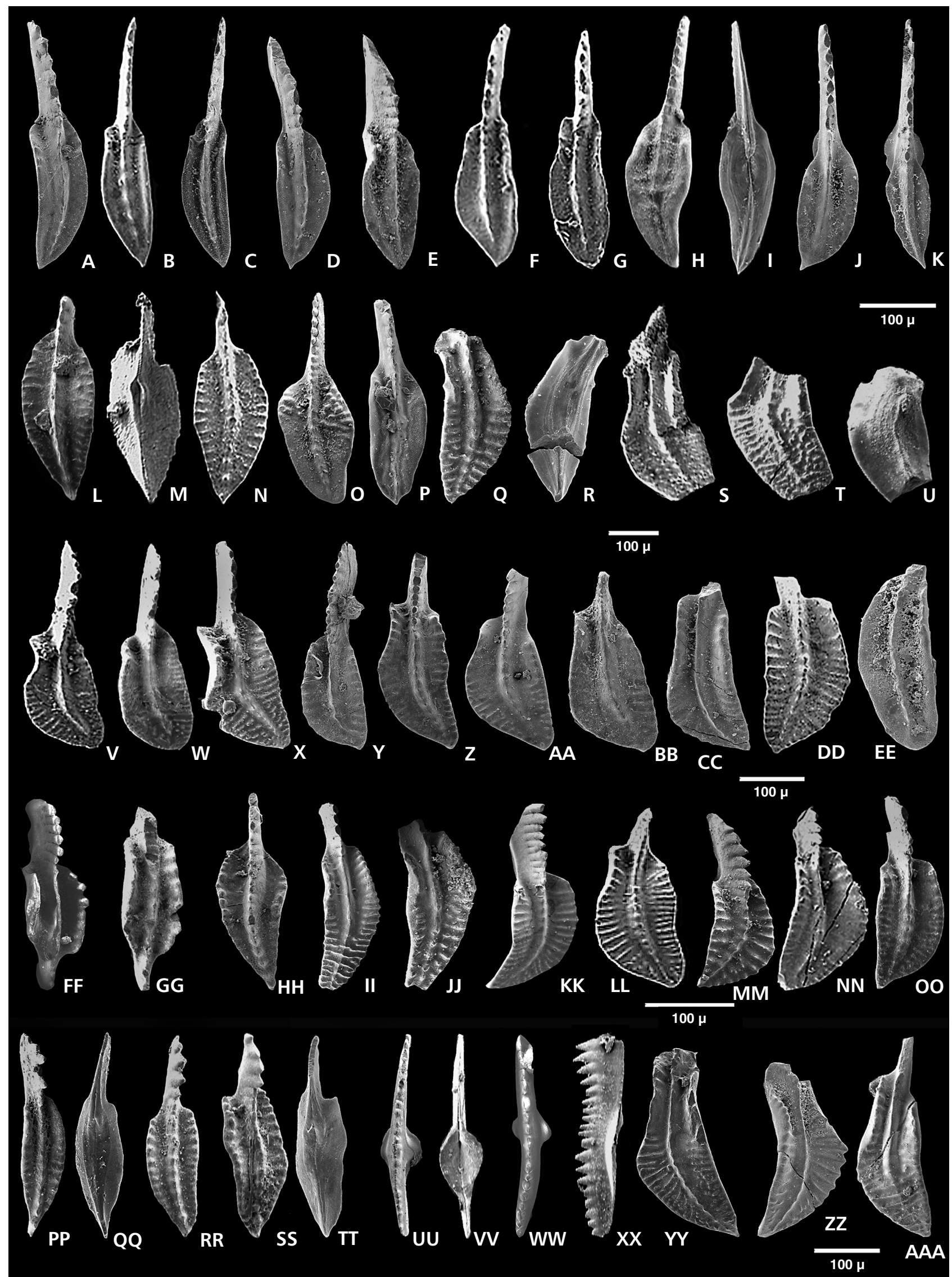
1966 Ancyrodella curvata (Branson \& Mehl). - Glenister \& Klapper, p. 789, pl. 86, fig. 13-15.

1993 Ancyrodella curvata (Branson \& Mehl). - Ji \& Ziegler, pp. 51, 52, pl. 2, figs 4, 5, 10 .

1999 Ancyrodella curvata (Branson \& Mehl). - Yazdi, p. 183 , pl. 4, figs $12-15$.

2007 Ancyrodella curvata (Branson \& Mehl). - Gholamalian, p. 466, fig. 9c.

Material. - 14 specimens.

Remarks. - A broadly triangular conodont element with pointed lobe developed on the inner margin and two pointed lobes developed on the outer margin, one pointing anteriorly and the second postero-laterally. The free blade extends as a carina to the posterior margin. Although the Iranian materials are mostly broken, they can be referred to Ancyrodella curvata by the shape of the lobes.

Stratigraphic range. - From the Lower hassi to the topmost linguiformis zones (Ji \& Ziegler 1993).

Order Prioniodontida Dzik, 1976

Family Icriodontidae Müller \& Müller, 1957

\section{Genus Icriodus Branson \& Mehl, 1938}

Type species. - Icriodus expansus Branson \& Mehl, 1938.
Icriodus alternatus alternatus Barnson \& Mehl, 1934 Figure $9 \mathrm{~F}-\mathrm{K}$

1934 Icriodus alternatus; Branson \& Mehl, p. 225, pl. 13, figs 4-6.

1975 Icriodus alternatus Branson \& Mehl. - Klapper in Ziegler (ed.), p. 69, Icriodus - pl. 3, figs 5, 6 (cum syn.).

1984 Icriodus alternatus alternatus Branson \& Mehl. Sandberg \& Dreesen, p. 158, pl. 2, figs 5, 11 (cum syn.).

2003 Icriodus alternatus alternatus Branson \& Mehl. Corradini, p. 92, pl. 2, figs 9-12.

Studied material. - 277 specimens.

Remarks. - Sandberg \& Dreesen (1984) proposed two morphotypes for I. alt. alternatus, according to the cross section of denticles of the medial row that may be rounded or laterally compressed. They reported also that the two morphotypes have the same stratigraphic distribution and that (p. 151) "in some faunas both morphotypes are present, whereas in other faunas one or the other morphotype is dominant or occurs exclusively". In the studied material both the morphologies are present, even if a majority of specimens have elongated denticles; furthermore a few specimens alternate elongated and rounded denticles in the median row. Therefore, considering that the two proposed morphotypes have no apparent utility, they are not accepted in this paper.

Figure 9. Conodonts from the Ghale-kalaghu, Howz-e-dorah 1 and 2 sections. • A-E - Icriodus xenium Nazarova, 1997; A - upper view of EUIC 10079, sample GH 3 (Lower rhenana Zone), B - upper view of EUIC 10080, sample GH 6 (Lower rhenana Zone), C - upper view of EUIC 10081, sample HDA 5 (Lower rhenana Zone), D - upper view of EUIC 10082, sample HDA 5 (Lower rhenana Zone), E - upper view of EUIC 10083, sample HDA 2 (Lower rhenana Zone). • F-K - Icriodus alternatus alternatus Sandberg \& Dreesen, 1984; F - upper view of EUIC 10084, sample GHA 5 (Middle to Uppermost crepida zones), G - upper view of EUIC 10085, sample GHA 1 (Lower crepida Zone), H - upper view of EUIC 10086, sample GH 6 (Lower rhenana Zone), I - upper view of EUIC 10087, sample HDA 16 (Lower rhomboidea Zone), J - upper view of EUIC 10088, sample HDA 12 (Lower crepida Zone), K - upper view of EUIC 10089, sample HDA 3 (Lower rhenana Zone). • L-P - Icriodus cornutus Sannemann, 1955a; L - upper view of EUIC 10090, sample HDA 13 (Lower crepida Zone), M - upper view of EUIC 10091, sample HDA 16 (Lower rhomboidea Zone), N - upper view of EUIC 10092, sample HDA 17 (Lower rhomboidea Zone), O - upper view of EUIC 10093, sample GH 7 (Upper triangularis Zone), P - upper view of EUIC 10094, sample GH 8 (Upper triangularis Zone). Q Q-U - Icriodus alternatus helmsi Sandberg \& Dreesen, 1984; Q - upper view of EUIC 10095, sample GHA 1 (Lower crepida Zone), R - upper view of EUIC 10096, sample GHA 4 (Middle to Uppermost crepida zones), S - upper view of EUIC 10097, sample HDA 7 (Upper triangularis Zone), T - upper view of EUIC 10098, sample HDA 11 (Lower crepida Zone), U - upper view of EUIC 10099, sample HBA 8 (Lower crepida Zone). • V-Z - Icriodus iowaensis iowaensis Youngquist \& Peterson, 1947; V - upper view of EUIC 10100, sample GHA 5 (Middle to Uppermost crepida zones), W - upper view of EUIC 10101, sample GHA 5 (Middle to Uppermost crepida zones), X - upper view of EUIC 10102, sample HDA 17 (Lower rhomboidea Zone), Y - upper view of EUIC 10103, sample HDA 9 (Upper triangularis Zone), Z - upper view of EUIC 10104, sample HBA 7 (Upper triangularis Zone). AA - Icriodus deformatus deformatus Han, 1987; upper view of EUIC 10105, sample HDA 6 (Upper triangularis Zone). • BB-EE - Pelekysgnathus serradentatus Capkinoglu, 1991 ; BB - upper view of EUIC 10106, sample GH 7 (Upper triangularis Zone), CC - upper view of EUIC 10107, sample GHA 5 (Middle to Uppermost crepida zones), DD - upper view of EUIC 10108, sample HDA 9 (Upper triangularis Zone). EE, FF, HH, JJ - Pelekysgnathus inclinatus Thomas, 1949; EE - lateral view of EUIC 10109, sample HDA 11 (Lower crepida Zone), FF - lateral view of EUIC 10110, sample HDA 12 (Lower crepida Zone), HH - lateral view of EUIC 10111, sample GHA 5 (Middle to Uppermost crepida zones), JJ - upper view of EUIC 10112, sample HBA 8 (Lower crepida Zone). - GG, II - Pelekysgnathus brevis Sandberg \& Dreesen, 1984; GG - lateral view of EUIC 10113, sample GH 5 (Lower rhenana Zone), II - lateral view of EUIC 10114, sample HDA 4 (Lower rhenana Zone). KK - Scaphignathus velifer velifer Helms, 1959; upper view of EUIC 10115, sample GHA 9 (velifer Zone). $\bullet$ LL - Polygnathus semicostatus Branson \& Mehl, 1934; upper view of EUIC 10116, sample GHA 4 (Middle to Uppermost crepida zones). 


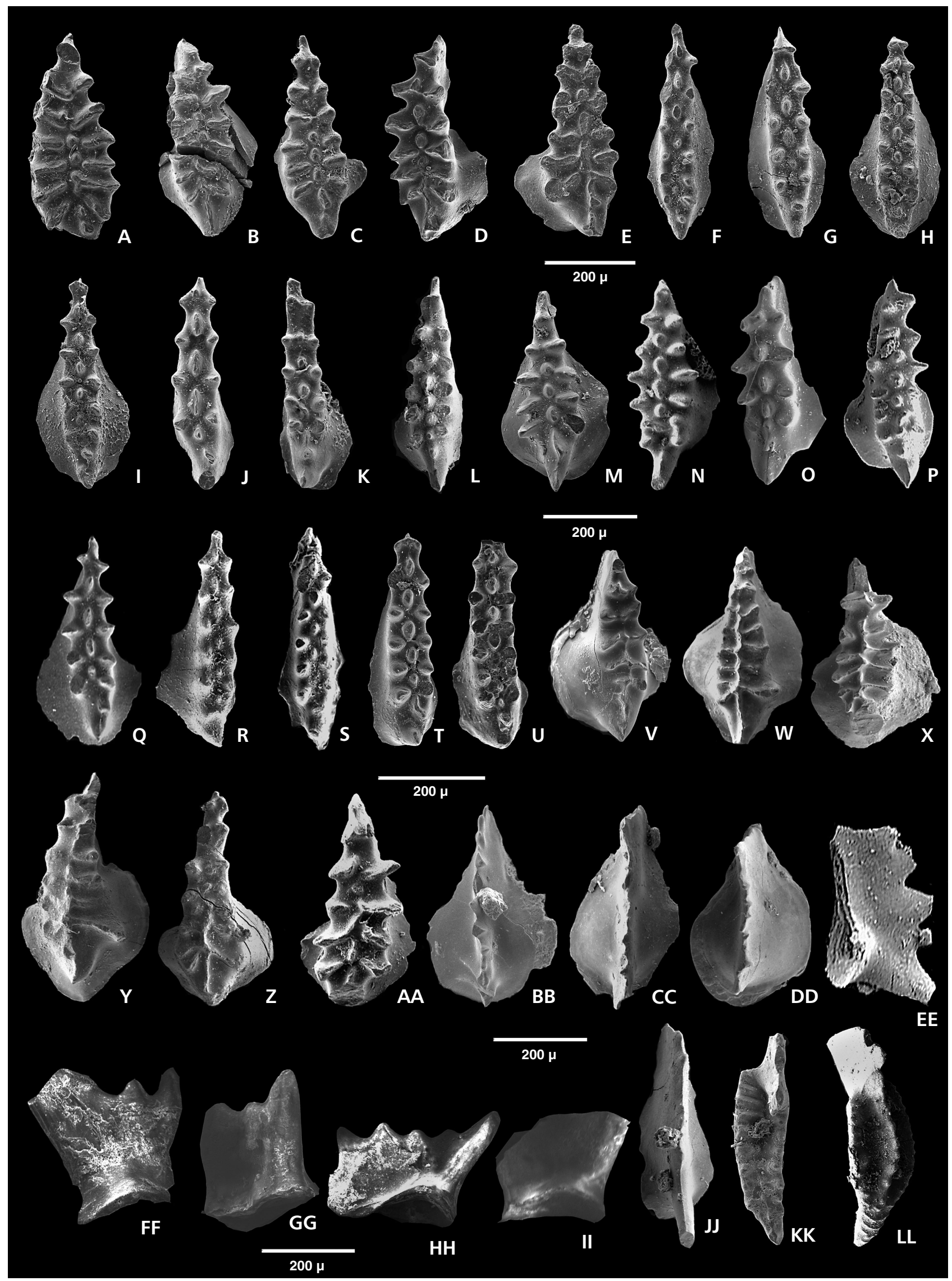


Stratigraphic range - From the Lower rhenana Zone to the Uppermost crepida Zone (Bultynck 2003).

\section{Icriodus iowaensis iowaensis} Youngquist \& Peterson, 1947 Figure 9V-Z

1984 Icriodus iowaensis iowaensis; Youngquist \& Peterson, p. 247, pl. 37, figs 22-24, 27-29.

1984 Icriodus iowaensis iowaensis Youngquist \& Peterson. - Sandberg \& Dressen, pp. 159, 160, pl. 1, figs 7-11 (cum syn.).

1985 Icriodus iowaensis iowaensis Youngquist \& Peterson. - Klapper \& Lane, p. 920, figs 11.7-11.10.

1991 Icriodus iowaensis iowaensis Youngquist \& Peterson. - Johnston \& Chatterton, pl. 3, figs 21-24.

1992 Icriodus iowaensis iowaensis Youngquist \& Peterson. - Savage, p. 280, figs 2.1-2.6.

Studied material. - 279 specimens.

Remarks. - I. iowaensis iowaensis is characterized by having a low cusp and conspicuous ridges connecting denticles. The ridges connect at least some of the medial-row denticles and join many lateral-row denticles to those of the medial row. In lateral view has the posterior cusp and all or most denticles are of about equal height. Sandberg \& Dreesen (1984) report on variability of the size of the platform, from broad platform and widely expanded basal cavity to narrow specimens.

In the studied material all the specimens have an expanded basal cavity and a broad platform.

Stratigraphic range. - According to Bultynck (2003) Icriodus iowaensis iowaensis ranges from the linguiformis Zone to the Lower rhomboidea Zone. Ziegler \& Sandberg (1990, p. 21) report the occurrence of early forms in the upper part of Upper rhenana Zone. In the Ghale-kalaghu section the species occur also in the uppermost part of the Lower rhenana Zone

\section{Genus Pelekysgnathus Thomas, 1949}

Type species. - Pelekysgnathus inclinatus Thomas, 1949.

\section{Pelekysgnathus serradentatus Capkinoglu, 1991} Figures 9BB-DD

1991 Pelekysgnathus serradentatus; Capkinoglu, pp. 351, 352, pl. 1, figs 1-3.

2000 Pelekysgnathus serradentatus Capkinoglu. - Capkinoglu \& Gedik, p. 78, pl. 1, figs 1-3.
2007 Pelekysgnathus serradentatus Capkinoglu. - Gholamalian, p. 468, figs $10 \mathrm{E}, \mathrm{F}$.

Material. - 59 specimens.

Remarks. - Pelekysgnathus serradentatus is characterized by lacking a prominent posterior cusp, by a very broad, expanded basal cavity and by a peculiar irregular shape of denticles that are somehow irregularly laterally expanded. Our material fit well in the original diagnosis of the species (Capkinoglu 1991). Bahrami et al. (2011b) described as Pel. cf. serradentatus a few specimens from southern Iran, with shape similar to the holotype (Capkinoglu 1991, pl. 1, fig. 1), but differing by a laterally compressed denticulation. This material comes from a slightly younger stratigraphic level, and indicates a possible evolutionary trend from a laterally expanded to a laterally compressed denticulation. Pelekysgnathus serradentatus seems to have a limited geographical distribution, being documented up to now only from Turkey and Iran.

Stratigraphic range. - The species was reported from the Middle triangularis Zone to the lower part of an undifferentiated crepida Zone (Capkinoglu \& Gedik 2000). The studied material comes from the Upper triangularis to the Uppermost crepida Zone.

\section{Conclusions}

The conodont fauna from three sections in the Shotori range allows detailed biostratigraphy across the Frasnian-Famennian boundary in the area. A hiatus spanning from the Upper rhenana into the Middle triangularis Zone is documented. The older Famennian strata are represented by white sandstones/quartzites with subordinate minor limestone lenses, deposited in a shallow water environment. More to the North, in the northern part of the Shotori Range Gholamalian et al. (2009) reported a similar hiatus characterized by a more diverse pelagic fauna (Kale-sardar section) and inferred a generally deeper water environment. Therefore different sedimentary environments occurred in the northern part and in the southern part of the Shotori Range during the Late Devonian, characterized by deeper and shallower water, respectively.

\section{Acknowledgements}

Department of Geology, University of Isfahan provided financial and technical supports. Thanks are due to Iliana Boncheva and Andrey Zhuravlev for giving useful comments and their help in taxonomic identifications. We are deeply grateful to Yury A. Gatovsky and Carine Randon for critical revision of the manuscript.

This paper is a contribution to IGCP 596-Climate change and biodiversity patterns in the Mid-Paleozoic (Early Devonian to Late Carboniferous). 


\section{References}

Ashouri, A.R. 2004. Late Devonian and Middle-Late Devonian conodonts from eastern and northern Iran. Revista Española de Micropaleontología 3, 355-365.

Assereto, R. 1963. The Paleozoic formations in central Elburz (Iran). Rivista Italiana di Paleontologia e Stratigrafia 69, 503-543.

Bahrami, A., Corradini, C. \& Yazdi, M. 2011a. Upper Devonian-Lower Carboniferous conodont biostratigraphy in the Shotori Range, Tabas area, Central-East Iran Microplate. Bollettino della Società Paleontologica Italiana 50(1), 35-53.

Bahrami, A., Gholamalian, H., Corradini, C. \& Yazdi, M. 2011b. Upper Devonian conodont biostratigraphy of Shams Abad section, Kerman Province, Iran. Rivista Italiana di Paleontologia e Stratigrafia 117(2), 199-209.

Beinert, R.J., Klapper, G., SAndberG, C.A. \& Ziegler, W. 1971. Revision of Scaphignathus and description of Clydagnathus? ormistoni n. sp. (Conodonta, Upper Devonian). Geologica et Palaeontologica 5, 81-91.

Berberian, M. \& King, G.C.P. 1981. Towards a paleogeography and tectonic evolution of Iran. Canadian Journal of Earth Sciences 18, 210-265. DOI 10.1139/e81-019

Bozorgnia, F. 1973. Paleozoic Foraminiferal Biostratigraphy of Central and East Alborz Mountains, Iran. National Iranian Oil Company, Geological Laboratories Publication 4, 1-185.

Branson, E.B. \& Mehl, M.G. 1934. Conodonts from the Grassy Creek Shale of Missouri. The University of Missouri Studies 8, 171-259.

Branson, E.B. \& Mehl, M.G. 1938. The conodont genus Icriodus and its stratigraphic distribution. Journal of Paleontology 12, 156-166.

Bultynck, P. 2003. Devonian Icriodontidae: biostratigraphy, classification and remarks on paleoecology and dispersal. Revista Española de Micropaleontologia 35(3), 295-314.

Capkinoglu, S. 1991. A new Pelekysgnathus species from the Lower Famennian of the Taurides, Turkey. Bollettino della Società Paleontologica Italiana 30, 349-353.

CAPKInoglu, S. \& GediK, I. 1991. Late Devonian conodont fauna of the Gumusali Formation, the Eastern Taurides, Turkey. Turkish Journal of Earth Sciences 9, 69-89.

Corradini, C. 2003. Late Devonian (Famennian) conodonts from the Corona Mizziu sections near Villasalto (Sardinia, Italy). Palaeontographia Italica 98, 65-116.

Corradini, C. 2008. Revision of Famennian-Tournaisian (Late Devonian-Early Carboniferous) conodont biostratigraphy of Sardinia, Italy. Revue de Micropaleontologie 51, 123-132. DOI 10.1016/j.revmic.2007.02.005

DREESEN, R. \& ORCHARD, M. 1974. Intraspecific morphological variation within Polygnathus semicostatus Branson \& Mehl, 1-10. In Bouckaert, J. \& Streel, M. (eds) Micropaleontological Limits from Emsian to Visean. International Symposium on Namur 1974. Geological Survey of Belgium 21.

DzIK, J. 1976. Remarks on the evolution of Ordovician conodonts. Acta Palaeontologica Polonica 21, 395-455.

Gholamalian, H. 2007. Conodont biostratigraphy of the Frasnian-Famennian boundary in the Esfahan and Tabas areas, central Iran. Geological Quarterly 51, 453-476.
Gholamalian, H., Ghorbani, M. \& Sajadi, S.H. 2009. Famennian conodonts from Kal-e-Sardar section, Eastern Tabas, Central Iran. Rivista Italiana di Paleontologia e Stratigrafia 115(2), 141-158.

Glenister, B.F. \& KlAPPER, G. 1966. Upper Devonian conodonts from the Canning Basin, Western Australia. Journal of Paleontology 40(4), 777-842.

Golonka, J., Ross, M.I. \& Scotese, C.R. 1994. Phanerozoic paleogeographic and paleoclimatic modeling maps, 1-47. In Embry, A.F., Beauchamp, B. \& Glass, D.J. (eds) Pangea: Global environments and resources. Canadian Society of Petroleum Geology, Memoir 17.

Habibi, T., Corradini, C. \& Yazdi, M. 2008. Conodont biostratigraphy of the Upper Devonian-Lower Carboniferous Sharmirzad section, central Alborz, Iran. Geobios 41, 763-777. DOI 10.1016/j.geobios.2008.04.002

Hairapetian, V. \& YAZdi, M. 2003. Late Devonian conodonts from the Dalmeh sections, Northeast Ardekan, Central Iran. Courier Forschungsinstitut Senckenberg 245, 209-225.

HaN, Y. 1987. Study on Upper Devonian Frasnian/Famennian boundary in Ma-Anshan, Zhongping, Xiangzhou, Guangxi. Chinese Academy of Geological Sciences Bulletin 17, 171-194.

Hass, W.H. 1959. Conodonts from the Chappel Limestone of Texas. U.S. Geological Survey Professional Paper 294, 365-399.

Helms, J. 1959. Conodonten aus dem Saalfelder Oberdevon (Thuringen). Geologie 8, 634-677.

Hinde, G.J. 1879. On conodonts from the Chazy and Cincinnati group of the Cambro-Silurian and from the Hamilton and Genesee shale divisions of the Devonian in Canada and the United States. Geological Society of London Quarterly Journal 35(3), 351-369.

DOI 10.1144/GSL.JGS.1879.035.01-04.23

House, M.R. 2002. Strength, timing, setting and cause of midPalaeozoic extinctions. Palaeogeography, Palaeoclimatology, Palaeoecology 181, 5-25.

DOI 10.1016/S0031-0182(01)00471-0

HudDLE, J.W. 1934. Conodonts from the New Albany Shale of Indiana. Bulletins of American Paleontology 21, 186-323.

JI, Q. \& ZiEGLER, W. 1993. The Lali section: an excellent reference section for Late Devonian in south China. Courier Forschungsinstitut Senckenberg 157, 1-183.

KlapPeR, G. \& LANE, H.R. 1985. Upper Devonian (Frasnian) conodonts of the Polygnathus biofacies, N.W.T., Canada. Journal of Paleontology 59, 904-951.

Kononova, L.I., Alekseev, A.S., Barskov, I.S \& Reimers, A.N. 1996. New species of Polygnathid assemblages from the Frasnian Stage of the Moscow Syneclise. Paleontologicheskii Zhurnal 3, 94-99.

KuZmin, A.V. 1990. Asimmetricheskiye pary platformennykh elementov u nekotorykh predstaviteley roda Polygnathus (konodonty). Paleontologicheskii Zhurnal 4, 66-74.

MüLLER, K.J. \& MüLlER, E.M. 1957. Early Upper Devonian (Independence) Conodonts from Iowa, part I. Journal of Paleontology 31(6), 1069-1108.

NaZAROVA, V.M. 1997. New conodont species of the genus Icriodus from the Eifelian and Frasnian of the Russian Platform. Paleontologicheskii Zhurnal 6, 636-640. 
Ovnatanova, N. 1969. Novye verkhnedevonskie konodonty tsentralnykh rayonov Russkoy platformy in Timana. In Fauna i stratigrafiya paleozoya Russkoy platformy, 39-141.

Ovnatonova, N.S. \& Kononova, L.I. 2001. Conodonts and Late Devonian (Frasnian) biostratigraphy of central regions of Russian platform. Courier Forschungsinstitut Senckenberg 233, $1-115$.

PANDER, C.H. 1856. Monographie der fossilen Fische des Silurischen Systems der Russisch-Baltischen Gouvernments. 83 pp. Buchdruckerei der Kaiserlichen Akademie der Wissenschaften, Petersburg.

Pujol, F. 2005. Chemostratigraphy of some key European Frasnian-Famennian boundary sections (Germany, Poland, France). 131 pp. PhD thesis, Universität Karlsruhe (TH), Karlsruhe.

RACKI, G. 1998. Frasnian-Famennian biotic crisis; undervalued tectonic control? Palaeogeography, Palaeoclimatology, Palaeoecology 141, 177-198.

DOI 10.1016/S0031-0182(98)00059-5

SANDBERG, C.A. \& DreESEN, R. 1984. Late Devonian icriodontid biofacies models and alternate shallow water conodont zonation, 143-178. In Clark, D.L. (ed.) Conodont biofacies and provincialism. Geological Society of America, Special Paper 196.

Sannemann, D. 1955a. Oberdevonische Conodonten (to II). Senckenbergiana lethaea 36, 123-156.

SANNEMANN, D. 1955b. Beitrag zur Untergliederung des Oberdevons nach Conodonten. Neues Jahrbuch für Geologie und Paläontologie, Abhandlungen 100, 324-331.

SAVAGE, N.M. 1992. Late Devonian (Frasnian and Famennian) conodonts from the Wadleigh Limestone, Southeastern Alaska. Journal of Paleontology 66(2), 277-292.

SCOTESE, C.R. 2001. Atlas of Earth-History. Paleogeography, Vol. 1. 52 pp. Paleomap Project, Arlington, Texas.

SCotese, C.R. \& Mc Kerrow, W.S. 1990. Revised world maps and introduction, 1-21. In MC KerRow, W.S. \& SCOTESE, C.R. (eds) Palaeozoic palaeogeography and biostratigraphy. Geological Society of America Memoir 12.

STAUFFER, C.R. 1938. Conodonts of the Olentangy Shale. Journal of Paleontology 12, 411-443.

Stocklin, J., Eftekhar-NeZhad, J. \& Hushmand-Zadeh, A. 1965 (reprinted 1991). Geology of the Shotori range (Tabas area, east Iran). Geological Survey of Iran, Reports 3, 1-69.

Stocklin, J. \& Nabavi, M.H. 1971. Explanatory text of the Boshruyeh Quadrangle map 1:250,000. Geological Survey of Iran, Geological Quadrangle J7, 1-50.

SweEt, W.C. 1988. The Conodonta: morphology, taxonomy, paleoecology, and evolutionary history of a long-extinct animal phylum. Oxford Monographs on Geology and Geophysics 10. 212 pp. Clarendon Press, New York.

Thомаs, L.A. 1949. Devonian-Mississippian Formations of southeast Iowa. Bulletin of the Geological Society of America 60, 403-138.

DOI 10.1130/0016-7606(1949)60[403:DFOSI]2.0.CO;2
Ueno, K., Watanabe, D., Igo, H., Kakuwa, Y. \& Matsumoto, R. 1997. Early Carboniferous Foraminifera from the Mobarak Formation of Shahmirzad, Northeastern Alborz Mountains, Northern Iran, 149-152. In Ross, C.A., Ross, J.R.P. \& Brenckle, P.L. (eds) Late Paleozoic foraminifera, their biostratigraphy, evolution, and paleoecology, and the mid-Carboniferous boundary. Cushman Foundation for Foraminiferal Research Special Publication 36.

Ulrich, E.O. \& BASSLER, R.S. 1926. A classification of the tooth-like fossils, conodonts, with descriptions of American Devonian and Mississippian species. Proceedings of the United States National Museum 68, 1-63.

DOI 10.5479/si.00963801.68-2613.1

Wendt, J., Hayer, J. \& Karimi BavandPour, A. 1997. Stratigraphy and depositional environment of Devonian sediments in northeast and east-central Iran. Neues Jahrbuch für Geologie und Paläontologie, Abhandlungen 206, 277-322.

Wendt, J., Kaufmann, B., Belka, Z., Farsan, N. \& Karimi Bavandpour, A. 2002. Devonian/Lower Carboniferous stratigraphy, facies patterns and palaeogeography of Iran. Part I. Southeastern Iran. Acta Geologica Polonica 52, 129-168.

Wendt, J., Kaufmann, B., Belka, Z., Farsan, N. \& Karimi BavandPour, A. 2005. Devonian/Lower Carboniferous stratigraphy, facies patterns and palaeogeography of Iran. Part II. Northern and Central Iran. Acta Geologica Polonica 55, 31-97.

YAZDI, M. 1999. Late Devonian-Carboniferous conodonts from Eastern Iran. Rivista Italiana di Paleontologia e Stratigrafia 105, 167-200.

YoungQuist, W.L. 1945. Upper Devonian conodonts from the Independence Shale (?) of Iowa. Journal of Paleontology 19, 355-367.

Youngquist, W.L. \& Peterson, R.F. 1947. Conodonts from the Sheffield Formation of north-central Iowa. Journal of Paleontology 21, 242-253.

ZIEGLER, W. 1959. Conodonten aus Devon und Karbon Südwesteuropas und Bemerkungen zur bretonischen Faltung (Montagne Noire, Massiv Mouthoumet, Span. Pyrenäen). Neues Jahrbuch für Geologie und Paläontologie, Monatshefte, 289-309.

ZIEGLER, W. 1960. Conodonten aus dem Rheinischen Unterdevon (Gedinnium) des Remscheider Sattels (Rheinisches Schiefergebirge). Paläontologische Zeitschrift 34, 169-201.

ZIEGLER, W. 1962. Taxionomie und Phylogenie Oberdevonischer Conodonten und ihre stratigraphische Bedeutung. Abhandlungen des Hessischen Landesamtes für Bodenforschung 38, $1-166$.

Ziegler, W. \& SANDBerg, C.A. 1984. Palmatolepis-based revision of upper part of standard Late Devonian conodont zonation. Geological Society of America Special Paper 196, 179-194.

ZiEgler, W. \& SAndberg, C.A. 1990. The Late Devonian Standard Conodont Zonation. Courier Forschungsinstitut Senckenberg 121, 1-115. 